\title{
The caddisfly genus Nectopsyche: new gemma group species from Costa Rica and the Neotropics (Trichoptera:Leptoceridae) ${ }^{1}$
}

\author{
RALPH W. HOLZENTHAL \\ Department of Entomology, University of Minnesota, \\ St. Paul, Minnesota 55108 USA
}

\begin{abstract}
Generic-level diagnoses are provided for adult males, females, and larvae of the longhorned caddisfly genus Nectopsyche Müller (Trichoptera:Leptoceridae). In addition, seven new Costa Rican species in the gemma species group are described and illustrated: $N$. exophthalma n. sp., $N$. monticola n. sp., N. onyx n. sp., N. ortizi n. sp., (also known from Argentina, Brazil, Guyana, Mexico, Panama, Peru, Surinam, and Venezuela), N. tapanti n. sp., N. tuanis n. sp., and N. utleyorum n. sp. The new species are compared with two previously described gemma group species also known from Costa Rica, N. argentata Flint and N. gemmoides Flint, and these, too, are diagnosed and illustrated.
\end{abstract}

Key words: Nectopsyche, new species, Trichoptera, Costa Rica, Neotropics, taxonomy, systematics.

Adult caddisflies are generally considered to be rather somber colored, drab insects. Indeed, most species are various shades and combinations of brown, grey, yellow, or black. Only a small percentage of species could be considered brightly colored as is the case in the genus $\mathrm{NeC}$ topsyche. The adults of most Nectopsyche species are striking in appearance due to the presence of colored hairs and scales, many of a metallic or iridescent character, on the forewings. They are among the most beautifully colored of all Trichoptera. In fact, identity of Nectopsyche species is based largely on the coloration of the body and forewings, male genitalia being rather uniform in structure throughout the genus. The modified setae making up these color patterns are easily rubbed off specimens captured roughly and stored in fluids. These caddisflies should be collected in dry, clean, cyanide killing jars, handled very carefully so as not to rub off the hairs and scales, and mounted on pins.

The genus Nectopsyche, a member of the longhorned caddisfly family Leptoceridae, contains 50 described species. In addition, seven new species from Costa Rica are described in the present paper. Members of the genus are restricted to the New World where they are found in southern Canada, the United States, Mexico, Central America, the Greater Antilles, and most of South America. The greatest diversity of species occurs in the tropical Brazilian Subregion of the Neotropics, especially the northern An-

\footnotetext{
${ }^{1}$ Studies in Neotropical Leptoceridae (Trichoptera) No. 10.
}

des and Amazonian lowlands; only a few species live in the temperate Chilean Subregion.

Larvae are well known for both the Nearctic fauna (Vorhies 1909, Elkins 1936, Ross 1944, Haddock 1977, Wiggins 1977, Daigle and Haddock 1981) and Neotropical fauna (Marlier 1964, Roback 1966, Flint 1968, Botosaneanu and Flint 1982, Holzenthal 1985, Roldán Pérez 1988). They generally build long, slender, tubular cases of sand grains or plant material or both. They inhabit small and large lentic and lotic habitats. In Costa Rica, larvae have been collected from sluggish lowland streams below $10 \mathrm{~m}$ elevation and cold mountain brooks at over $3000 \mathrm{~m}$ elevation as well as at intermediate elevations. Larvae are classified trophically as shredder-herbivores and gatherers (Merritt and Cummins 1984). Larvae of some species have rows of long setae on the hind legs, enabling them to swim, a behavior reflected in the name of the genus.

Haddock (1977) provided a systematic review of the genus, but treated only the North American species. No complementary treatment of the systematics of the Neotropical species has ever been attempted. A partial explanation is the difficulty recognizing and defining species, especially when individuals have lost their colored hairs and scales. Also, the types of many species, especially those described by Navás, are lost, or in poor condition, or have been inadequately described. Fortunately, mainly through the efforts of Schmid (1949) and Flint (1972, 1974a, 1974b, 1981, 1982, 1983, 1991) the identity of many of Navás's Nectopsyche species are now known and several have been placed in 
synonymy. The identity of only three of his species remains questionable: N. brethesi, $N$. ful$v a$, and N. thalina (O. S. Flint, Jr., Smithsonian Institution, personal communication).

Within the genus, informal species groups have been recognized with member species conforming to similar genitalic ground plans and similar patterns of coloration. Differences in color and genitalia between species groups are distinct, but differences among species within groups are more subtle. Detailed study of the male genitalia, as well as non-genitalic characters, including coloration, eye size, and forewing length, for the gemma group species has shown that these characters usually covary and, if taken together, are useful in defining species. In a few species (e.g., Nectopsyche onyx n. sp., and $N$. utleyorum n. sp.), differences in color pattern and forewing length are present, but no discernible differences occur in the genitalia. I am, therefore, basing my species definition primarily on diagnostic differences in color pattern as well as differences in male genitalia when they occur. This procedure may result in the splitting of a di- or polymorphic species, but there have been no reports of polymorphism in the Leptoceridae (other than sexual dimorphism). In both color and genitalia, species differences are often subtle, but apparently stable even in sympatry. While there is some intraspecific variation, I have seen little interspecific overlap in color and other characters. However, few species in other groups of Nectopsyche have been diagnosed adequately, and no attempt has been made to define natural, monophyletic clusters of species.

This paper marks the initiation of a revision of the Neotropical members of the genus and consists of the description of several new species, most endemic to Costa Rica, in the so-called gemma species group (first mentioned by Flint [1981] as gemma section). In addition to the seven new species described in this paper, other members of the gemma group include $N$. argentata Flint, N. aureofasciata Flint, N. flavofasciata (Ulmer), N. gemma (Müller), N. gemmoides Flint, and possibly $N$. cupreosquamosa Botosaneanu. Diagnoses of $N$. argentata and $N$. gemmoides, which occur in Costa Rica, are included in the present paper. Members of the group are characterized mainly by their bright, jewel-like coloration, especially of their forewings. All species are recognized by having the forewings covered with yellow or golden hairs (occasionally with darker hairs) and traversed by bands or stripes of white hairs or silvery scales, generally in the following pattern: one to several narrow longitudinal bands along the basal third of the wing and almost always with the area between $C$ and Sc filled with silver scales; generally two broad transverse silver bands at the midlength of the wing, often extending across the width of the wing; usually four areas of black scales between the arculus and the apex of $\mathrm{Cu} 1 \mathrm{~b}$ which are interspersed with patches of white hairs and silver scales; a series of large or small white and silver spots or irregular lines in the vicinity of the cord (the region around crossviens $r, r-m$, and $m-c u$ ); and, finally, two or three transverse bands at the apex of the wing, the apical-most of which may be broken. In the female, the basal wing stripes are often not as distinct as in the male and the apical transverse band is absent (occasionally absent in some males as well). The differences in color patterns among the species are subtle but stable, and correlate well with distinct, but again subtle, differences in male genitalia. Male genitalia are characterized by having apically forked preanal appendages (ventral fork is thin and bladelike), basally broad inferior appendages, and a phallic apparatus with several endothecal spines. Of all the species treated in the present paper, $N$. ortizi n. sp. conforms least to the typical genitalic pattern. Therefore, I am not establishing monophyly for the gemma group based on its color pattern or genitalia and prefer to treat the group informally at this time.

\section{Methods}

Methods used in preparing, examining, and illustrating genitalia are those that are commonly in use in the study of Trichoptera. Specimens I collected in Costa Rica were captured in cyanide killing jars; I do not know the manner in which other specimens were collected. Terminology used for genitalia (Figs. 1, 2) and wing venation (Fig. 3) is from Schmid (1980) and for larval characters from Wiggins (1977). In the descriptions of the species, forewing length is given to the nearest $0.5 \mathrm{~mm}$.

Types of species described below are deposited in the collections of the National Museum of Natural History, Smithsonian Institution, Washington, D.C. (NMNH), the University of 

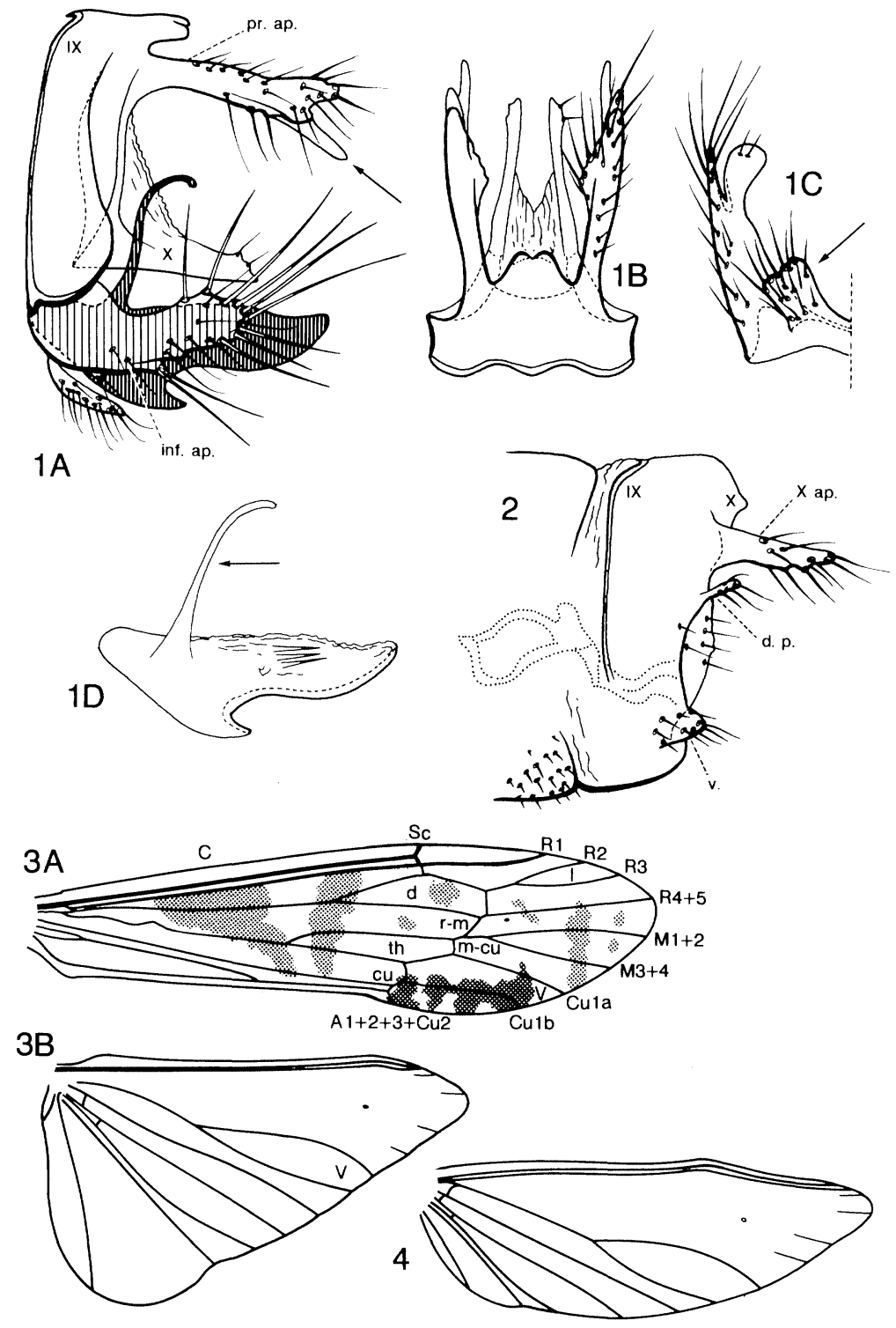

Figs. 1-4. Nectopsyche gemmoides Flint, male and female genitalia and wings. 1A-D.-Male genitalia: A, lateral; B, segments IX, X, dorsal; C, left inferior appendage, ventral; D, phallic apparatus, lateral. 2.-Female genitalia, lateral. 3.-Male wings: A. forewing, B. hind wing. 4.-Female hind wing. Abbreviations for genitalic structures: d.p. $=$ digitate process, inf. ap. $=$ inferior appendage, pr. ap. $=$ preanal appendage, $\mathbf{v} .=$ valve, $X$ ap. = appendage of $X, I X=$ abdominal segment IX, $X=$ abdomional segment $X$. Arrows highlight important diagnostic features discussed in the text.

Minnesota Insect Collection, St. Paul, Minnesota (UMSP), the Instituto Nacional de Biodiversidad, Santo Domingo, Costa Rica (INBIO), the Instituto de Biología, Universidad Nacional Autónoma de México, México (IBUNAM), and the Instituto Zoología Agrícola, Maracay, Venezuela (IZAM).

\section{Nectopsyche Müller}

Type species: Setodes gemma Müller 1880, first included species.

Nectopsyche Müller 1879:38-40 [no included species].-Müller 1921:527, figs. 180c, 184e [larva, pupa].-Ulmer 1951:409 [resurrected 
as a genus].-Ulmer 1955:497.-Fischer 1966: 50 [as synonym of Leptocella].-Fischer 1972: 125 [as a distinct genus].-Flint 1974a:127 [Leptocella is a synonym; all species formerly in Leptocella transferred to Nectopsyche].Haddock 1977:382-421 [revision of North American species].-Wiggins 1977:14, 161, 162, 170 [larva; biology].-Schmid 1980:186 [diagnosis].-Flint 1983:70 [diagnosis].-Flint 1991:93 [neotype of gemma designated].

Leptocella Banks 1899:213, 214 [Type species: Mystacides uwarowii Kolenati 1859, original designation].-Ulmer 1907:133, 137 [diagnosis].-Ulmer 1951:406, 411.-Ulmer 1955:507, 510 [larva, pupa].-Milne 1934:13.-Betten 1934:252, 263.-Ross 1944:210-213.-Fischer 1966:50-61 [catalog].-Fischer 1972:125 [catalog]. - Flint 1974a:127 [as synonym of $\mathrm{Nec}$ topsyche].

Brethesella Navás 1920:70 [Type species: Brethesella decorata Navás 1920, monobasic].-Fischer 1966:61 [catalog].-Flint 1982:56, 57 [as synonym of Nectopsyche].

\section{Generic diagnosis}

Adult.-Color white, yellow, brown, or golden; with white or golden hairs and scales emanating from setal warts; antennal segments usually with basal ring of white hairs. Forewing with distinctive pattern of transverse, longitudinal, zig-zag, or irregular bands, rows or spots of white, silver, brown, golden, blue or black, often metallic or iridescent, hairs and scales; many species with four patches of black scales along Culb; membrane of forewing usually with light brown pigmented areas (Fig. 3A). Eye size variable, often very large, especially in male, in which case interocular distance small (Haddock 1977, figs. 13-18). Labial palps reduced in both sexes. Midcranial sulcus present; mesopleural katepisternum truncate. Forewing (Fig. 3A) with forks I and V present, fork I with short petiole; fork of $M$ petiolate; discoidal cell $(d)$ short, broad; thyridial cell $(t h)$ short. Hind wing broad (i.e., anal region expanded) in male (Fig. 3B), narrow in female (Fig. 4); $R$ and $M$ atrophied basally and fork $\mathrm{V}$ deep (about equal in length to its petiole) in both sexes. Tibial spur formula 0-22. Abdominal haemo-branchial apparatus well developed (Schmid 1980, fig. 703).

Male genitalia (Fig. 1).-Abdominal segment IX with sternum completely absent; pleural re- gion narrow; tergum somewhat produced posteriorly. Preanal appendages ( $p r . a p$.) long and narrow, blunt or forked, with or without thin, blade-like, apicoventral projection and apical setae. Segment $X$ highly modified, with thin, lightly sclerotized lateral processes situated very low, almost at level of inferior appendages; usually narrow and pointed; connected mesally by membrane and to bases of preanal appendages by long, thin, vertical sclerotized straps (possibly extended pleural region of segment $X$; these processes have been misinterpreted as posterolateral extensions of segment IX by some authors). Inferior appendages (inf. ap.) short; connected basally by narrow, sclerotized bridge; fused bases of inferior appendages perhaps forming the functional equivalent of sternum IX; each inferior appendage with basoventral digitate or quadrate setose process (often slightly asymmetrical on right and left sides of specimen) or large, flat, scoop-like process; apex of inferior appendage generally flat and truncate or pointed in lateral view; bearing rounded or truncate apicomesal lobe (possibly second article of inferior appendage) and many long, prominent setae. Phallic apparatus large, situated between inferior appendages; phallic apodeme short; phallic shield with long, curved, slender, generally capitate, external periphallic processes ("swan's neck processes" of Ross [1944] incorrectly considered by him and other authors to be mesobasal processes of the inferior appendages and by Haddock [1977] to be associated with segment X; see Morse [1975] for the correct interpretation of these processes); phallobase large, trough-like; endothecal membranes highly erectile, often bearing spine-like endothecal setae; phalicata absent or very lightly sclerotized; endophallic membranes erectile; phallotremal sclerite small, U-shaped in dorsal view.

Female genitalia (Fig. 2).-Very simple; appendages of segment $X(X . a p$.$) long, narrow;$ valves $(v$.) short, lobe-like, situated ventrolaterally; pair of very short, digitate processes (d. p.) present midlaterally, below appendages of $\mathrm{X}$.

Larva.-Head (Figs. 5A, B): narrow; ventral apotome short, triangular; subocular ecdysial line present (Fig. 5A); head setal pattern as in Figure 5E, typical for family; mandibles short and wide, with short, rounded to pointed teeth; antennae long and slender. Thorax (Figs. 5A, 


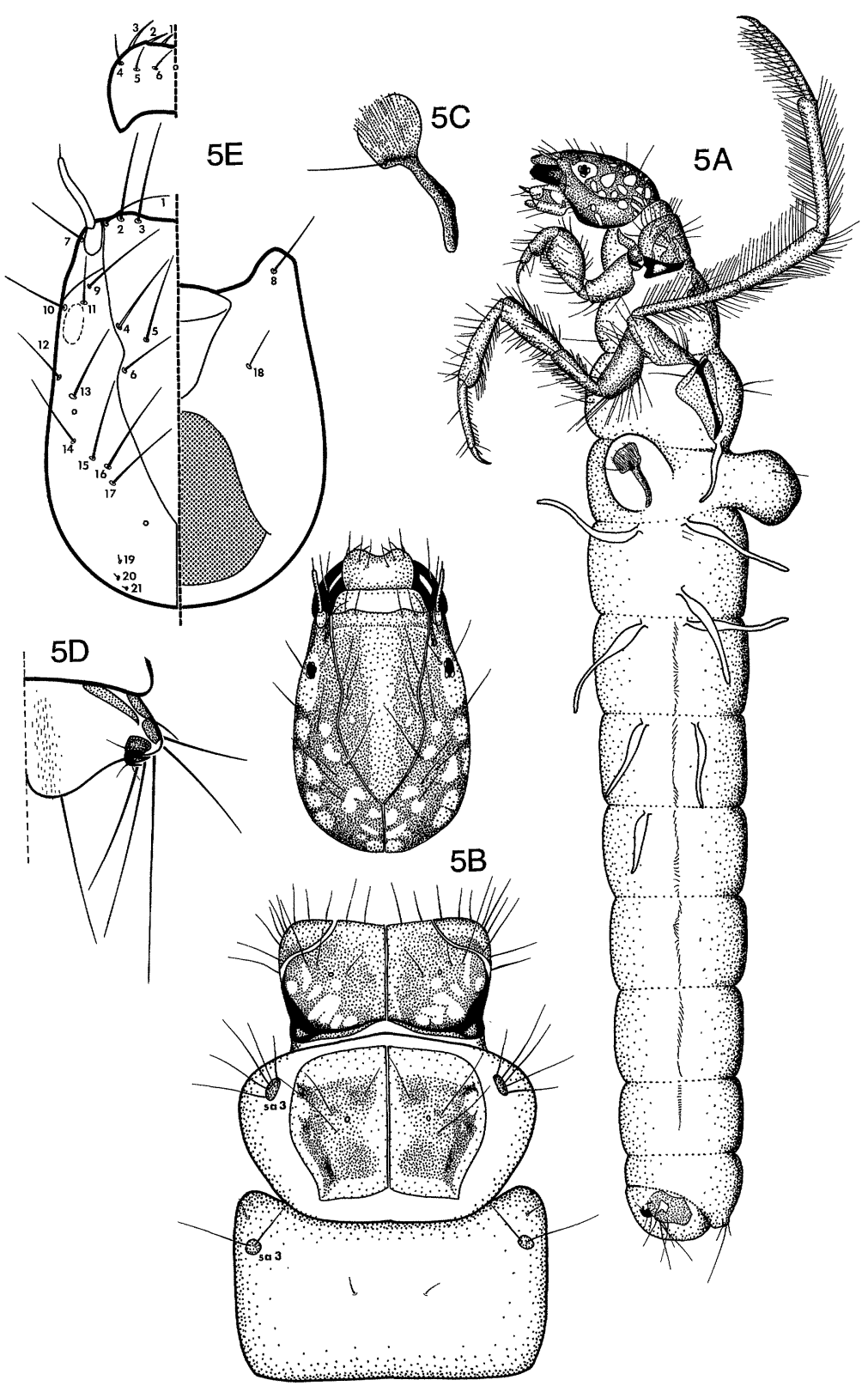

Fig. 5. Nectopsyche gemmoides Flint, larva. A.-Larva, lateral. B.-Head and thorax, dorsal. C.-Lateral hump sclerite, lateral. D.-Abdominal segments IX and X, ventral. E.-Head setal pattern, dorsal on the left and ventral on the right.

B): pronotum with anterolateral corners delimited by ecdysial line; anterior and lateral margins entire (Fig. 5B), crenulate (Marlier 1964, plate 19, fig. 6), or with toothed lobes (Wiggins 1977, fig. 9.4G); mesonotum with pair of large medial sclerites, mesonotal sa3 sclerites small, oval; metanotum with small, oval sa3 sclerites, but otherwise without sclerites; thoracic setal pattern as in Figure 5B (see also Wiggins 1977, fig. 9.4B). Head and thoracic sclerites with diagnostic spots or bands (Haddock 1977, figs. 2633). Legs long and slender; hind tibia not subdivided; hind tibia and tarsus often with two parallel rows of long setae (Fig. 5A) or with 
ventral row of spine-like setae. Abdomen (Figs. 5A, D): lateral hump sclerite of abdominal segment I with round anterior portion bearing rows of fine microtrichia and with narrow, posterolateral, sclerotized extension (Fig. 5C); gills, when present, single, generally distributed as in Fig. 5A (see also Wiggins 1977, fig. 9.4A); lateral fringe present on segments III-VII; lateral tubercles present or VIII; ventral band of uniformly small spines beside anal opening (Fig. $5 D)$, or spines absent in the position.

Larval case.-Made of mineral fragments or plant material (sometimes arranged in spiral or transverse rows) or both, occasionally entirely of silk; usually long, straight, and cylindrical, often with one or more twigs or conifer needles extending beyond one end; a few species build flattened cases of leaf discs (Marlier 1964, plate 16, fig. 7; plt. 17, figs. 1, 2; plt. 18, fig. 1; plt. 23, fig. 1 ; plt. 28 , fig. 1 , plt. 30 , fig. 1 ; plt. 31 , fig. 1 ; Roback 1966, figs. 128, 137, 154, 156, 163, 166; Wiggins 1977, fig. 9.4C)

Remarks.-Monophyly for the genus is supported by several synapomorphies including, in the male genitalia: (1) sternum IX atrophied; (2) ventrally positioned processes of segment $X$; (3) inferior appendages with basoventral processes; (4) long, slender, curved phallic shield strips; the female genitalia by the general reduction and simplicity of external genitalic appendages, especially: (5) short, narrow appendages of $\mathrm{X}$; (6) reduced, nub-like valves; and (7) presence of small, digitate, mid-lateral processes on segment IX. Finally, Morse (1981) placed Nectopsyche and the Old World genus Parasetodes MacLachlan in the Nectopsychini based on the shared atrophication of the stems of $R$ and $M$ in the hind wing (Morse 1981, fig. 1).

\section{Nectopsyche argentata Flint Figs. 6, 14}

Nectopsyche argentata Flint 1991:94, figs. 357, 358, 411 [in part] [Type locality: Colombia, Dpto. Antioquia, Quebrada Honda, Marsella (12 km SW Fredonia); NMNH; $\delta$ ].

\section{Diagnosis}

In his description of this species, Flint (1991) mentioned that the size of the basoventral process of the inferior appendage (his "clasper") was elongate and terete, but rarely broader in some individuals. I have examined the Costa Rican paratypes of this species deposited in the University of Minnesota Insect Collection and find that all males have broad basoventral processes on the inferior appendage. In addition, these paratype specimens differ in coloration from the holotype (Flint 1991, figs. 357, 358, 411 ) in that they completely lack the patch of white hairs on the jugum of the forewing (visible in the photograph of the holotype, Flint 1991, fig. 411 and in Fig. 14A). Other distinct differences between the two forms show that the paratypes from Costa Rica represent a second, undescribed species which I describe below as $N$. utleyorum $n$. sp. In addition to the above mentioned characters, the two species differ in the punctation in the area of the cord (Figs. 14B, 22B): in N. argentata there are usually four small spots in this area (two small white spots posterior of two small silver spots), the basal-most of the silver spots is bordered by fuscous hairs, while the apical-most has a tiny patch of fuscous hairs apically; finally there is a tiny patch of fuscous hairs at the apex of Sc. In N. utleyorum the punctation over the cord is totally different, the area is dominated by a large, oval, silver spot bordered by fuscous hairs and posterior of which lie very small silver and white spots. The genitalia of the species are also different, in $N$. argentata there are distinct periphalic processes (also mentioned by Flint 1991). However, in N. utleyorum the phallus lacks periphallic processes or they are vestigial. The inferior appendages of $N$. argentata are broad basally, distinctly angulate basoventrally, and each has an angulate apex. In N. utleyorum the same appendages are narrower and more rounded basally and apically. Additionally, the basoventral process of each inferior appendage is digitate in N. argentata and broad in N. utleyorum. While these differences are slight they are consistent across many individuals and there is almost no overlapping variation between the two species.

\section{Redescription}

Adult (Fig. 14).-Forewing length $7.5 \mathrm{~mm}($ ( $)$, $5.5 \mathrm{~mm}$ (q). Head straw colored, covered with yellow hairs, dorsally with white scales and hairs bordering eyes and with white patch on vertex; antennal scapes yellow with narrow lateral and mesal stripes of white scales; antennal flagel- 

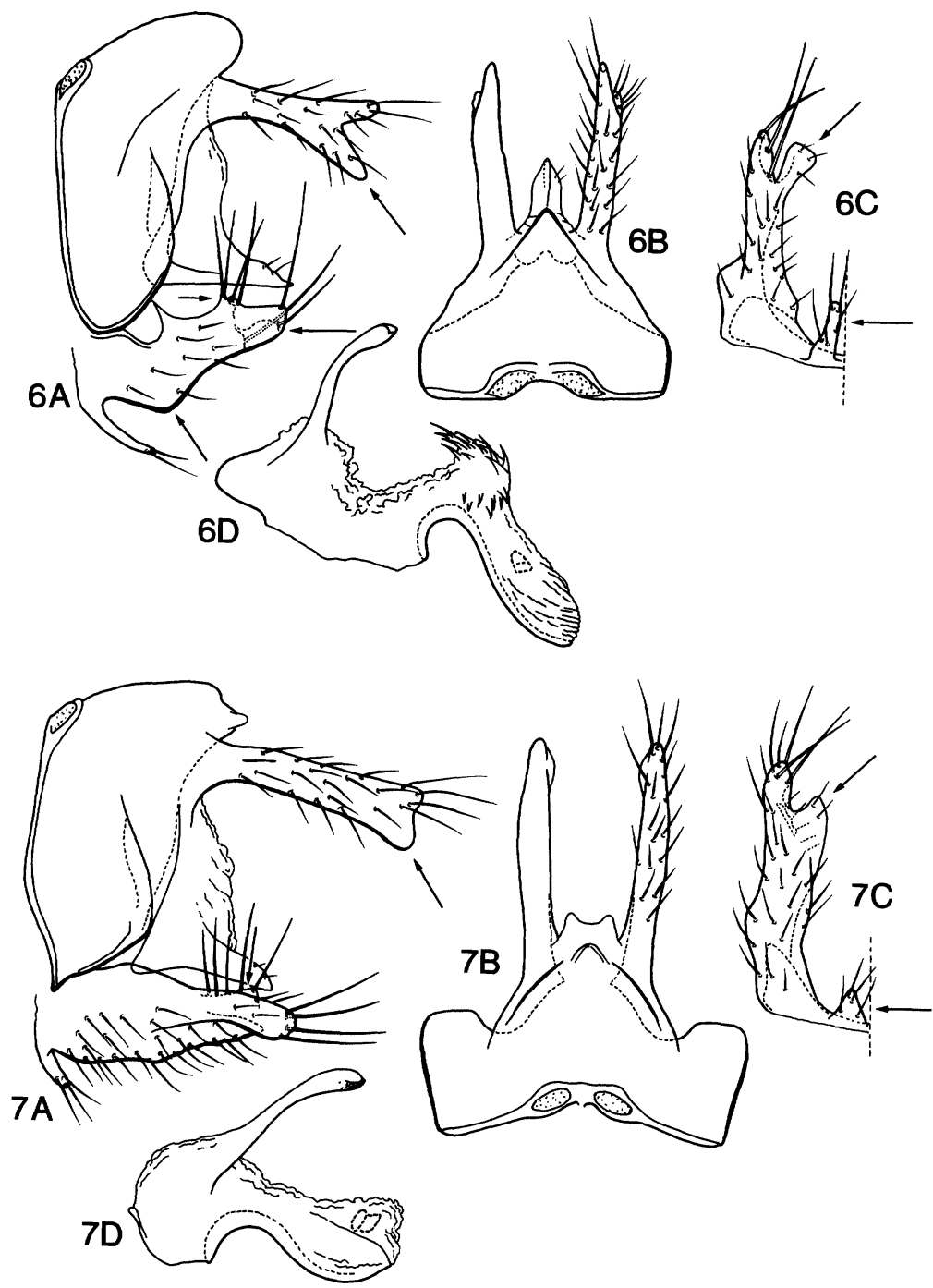

Fics. 6,7. Nectopsyche spp., male genitalia. 6.-N. argentata Flint. 7.-N. exophthalma new species. Structures and orientations are the same as those in Fig. 1, A-D. Arrows highlight important diagnostic features discussed in the text.

lomeres yellowish white. Eyes small. Thorax straw colored, covered with yellow and golden hairs; mesoscutum with elongate patch of white scales laterally; legs straw colored. Forewings covered with golden-yellow hairs. Base of each forewing with patch of white hairs on jugum, long stripe of silver scales along base of $\mathrm{A} 1+\mathrm{A} 2$ extending to anal border where the scales are white; shorter, often broken stripe of silver scales along base of $M$, and silver scales between $C$ and Sc extending to basal transverse band. Middle of forewing with two broad transverse bands of silver scales bordered by fuscous hairs: basalmost band extending from $\mathrm{C}$ to $\mathrm{Cu}$, narrowing along its length and tilted apicad; apical band extending across width of wing, slightly curved, bent apicad, and uniformly wide throughout its length. Four large spots of black scales along $\mathrm{Cu} 1 \mathrm{~b}$, these set in silver scales posteriorly and apically and with oval patch of white scales anteriorly, basal-most black spot $\pi$-shaped, remaining spots roughly figure-8-shaped, each connected by narrow longitudinal stripe of black scales; cord with series of small spots: usually 
two small white spots posterior of two small silver spots; basal-most silver spot bordered by fuscous hairs, apical-most with tiny patch of fuscous hairs apically; tiny patch of fuscous hairs at apex of Sc; three transverse apical wing bands: basal-most band often broken, white anteriorly, silver posteriorly; middle band white anteriorly, silver posteriorly, the silver bordered by fuscous hairs; apical band white, narrow, faint, often absent.

Male genitalia (Fig. 6).-Abdominal segment IX broad laterally; tergum broad, rounded, somewhat produced posteriorly. Preanal appendages long, setose, forked apically, with apicoventral fork thin, but setose. Segment $X$ lateral processes thin, narrow, their apices pointed, bearing small subapical setae. Inferior appendages broad basally, distinctly angulate basoventrally; angulate apically, each with subapicodorsal setose projection; apicomesal lobe truncate apically, with long setae near gap where apicomesal lobe originates from body of inferior appendage; basoventral process narrow, digitate. Phallic apparatus with distinct periphallic processes, each slightly enlarged and pointed apically; endothecal membranes highly erectile, bearing about two dozen spine-like setae; phallotremal sclerite small, U-shaped in dorsal view.

\section{Material examined}

COSTA RICA. Alajuela: Cerro Campana, $\sim 6 \mathrm{~km}$ (air) NW Dos Ríos, $10.9^{\circ} \mathrm{N}, 85.4^{\circ} \mathrm{W}$, el. $640 \mathrm{~m}, 15-$ 16.iii.1986, Holzenthal, Fasth, 19 (UMSP); Cerro Campana, R. Bochinche trib., $6 \mathrm{~km}$ (air) NW Dos Ríos, $10.945^{\circ} \mathrm{N}, 85.412^{\circ} \mathrm{W}$, el. $600 \mathrm{~m}, 22-23 . v i i .1987$, Holzenthal, Morse, Clausen, 10, 4 으 (UMSP); Cartago: km

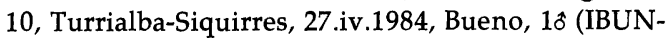
AM); Guanacaste: Parque Nacional Guanacaste, Estación Pitilla, R. Orosí, $10.991^{\circ} \mathrm{N}, 85.428^{\circ} \mathrm{W}$, el. $700 \mathrm{~m}$, 19-20.vi.1988, C. \& O. Flint, Holzenthal, 1 ( $(\mathrm{NMNH})$; Parque Nacional Guanacaste, Maritza, R. Tempisquito, $10.958^{\circ} \mathrm{N}, 85.497^{\circ} \mathrm{W}$, el. $550 \mathrm{~m}, 17-18 . v i .1988, \mathrm{C}$. \& O. Flint, Holzenthal, $2 \delta$ (NMNH); same, except 1920.vii.1987, Holzenthal, Morse, Clausen, $6 \hat{\delta}^{\circ} 2$ (UMSP); same, except 30-31.viii.1990, Huisman, Blahnik, Quesada, 9\% (UMSP); Q. Garcia, $10.6 \mathrm{~km}$ ENE Quebrada Grande, el. 470 m, 8.iii.1986, Holzenthal, Fasth, 1 \% (UMSP); R. Góngora (sulfur mine), 4 km (air) NE Q. Grande, $10.887^{\circ} \mathrm{N}, 85.470^{\circ} \mathrm{W}$, el. $590 \mathrm{~m}, 21 . v i i .1987$, Holzenthal, Morse, Clausen, 10 (UMSP); R. Los Ahogados, $11.3 \mathrm{~km}$ ENE Q. Grande, $10.865^{\circ} \mathrm{N}, 85.423^{\circ} \mathrm{W}$, el. 470 m, 7.iii.1986, Holzenthal, Fasth, 5\&, 19 (UMSP); same, except 26.vi.1986, Holzenthal, Heyn, Armitage,
2ิ, $2 \propto$ (UMSP). MEXICO. Chiapas: $20 \mathrm{~km}$ beyond Lagunas de Montebello, 8.iv.1979, Bueno, $3 \hat{\delta}$ (IBUNAM); Oaxaca: Metates, 17.iv.1983, Ibarra, $1 \delta$ (IBUNAM); Veracruz: Las Cabañas, 27.iii.1976, Bueno, 2 (IBUNAM). PERU. Cuzco: Paucartambo, Pte. San Pedro, $50 \mathrm{~km}$ NW Pilcopata, el. 1600 m, 2-3.ix.1988, Flint, Adams, $5 \hat{\delta}, 7$ 으 (NMNH); Madre De Dios: Manu, Erika (near Salvación), $550 \mathrm{~m}, 4$ 4-6.ix.1988, Flint, Adams, $1 \hat{\text { to }}$ (NMNH).

\section{Nectopsyche exophthalma new species Figs. 7, 15}

Nectopsyche species Flint 1991:95, figs. 361-362.

\section{Diagnosis}

This is probably the species mentioned by Flint (1991) from Antioquia, Colombia, as having large eyes. Indeed, its large eyes render it unique within the gemma group. It is also a small species and has relatively wider wings than other members of its group. The middle transverse wing band is also unique in being short. However, the species shares with $N$. argentata Flint, $N$. tapanti n. sp., and N. utleyorum n. sp. distinct longitudinal basal wing stripes. Its genitalia are similar to those of $N$. monticola $\mathrm{n}$. sp. only in that both have rather shallowly forked preanal appendages, but the inferior appendages of the large eyed species are totally different, especially in ventral view (Fig. 7C), from any other species described here.

\section{Description}

Adult (Fig. 15).-Forewing length $7 \mathrm{~mm}$ (o). Head straw colored, with yellow and white hairs, dorsally with white scales and hairs bordering eyes and with white patch on vertex; antennal scapes yellow with scattered white scales; antennal flagellomeres yellowish white. Eyes large, much wider than interocular distance when viewed ventrally. Thorax straw colored, covered with yellow and golden hairs; mesoscutum with elongate patch of white scales laterally; legs straw colored. Forewings covered with golden-yellow hairs. Base of each forewing with long stripe of silver scales along base of $\mathrm{A} 1+\mathrm{A} 2$, but not extending to anal margin, short stripe of silver scales along base of $\mathrm{M}$, and silver scales between $\mathrm{C}$ and Sc extending to basal-most transverse band. Middle of forewing with two broad transverse bands of silver scales bordered by fuscous hairs: basal-most band extending 
from $\mathrm{C}$ to slightly beyond $\mathrm{Cu}$, narrowing along its length and tilted apicad; apical-most band short, wide, extending only to about base of thyridial cell. Four very large spots of black scales along $\mathrm{Cu} 1 \mathrm{~b}$, these set in silver scales posteriorly and laterally, and with oval patch of white scales anteriorly, first or basal-most black spot large, U-shaped, second spot broken into two, third spot roughly figure- 8 shaped, fourth or apical-most spot roughly triangular, with extension along basal side of large silver spot; the basal and apical pairs of spots connected by narrow longitudinal stripes of black scales; cord with only single large oval silver spot bordered by fuscous hairs and tiny white spot near it; two wide transverse apical wing bands, both bands white anteriorly, silver posteriorly, the silver bordered by fuscous hairs.

Male genitalia (Fig. 7).-Abdominal segment IX broad laterally; tergum rounded, slightly produced posteriorly. Preanal appendages long, setose, only very slightly forked apically. Segment $X$ lateral processes thin, narrow, their apices pointed, bearing small subapical setae. Inferior appendages broad basally, narrowing apically; each with apex rounded and bearing long, prominent setae; subapicomesally with shelf bearing long, prominent setae; apicomesal lobe short, wide, slightly acute apically, widely separated from body of inferior appendage; basoventral process very short, triangular. Phallic apparatus with distinct periphallic processes, each slightly enlarged, pointed, and rugose apically; endothecal membranes highly erectile, but apparently lacking spine-like setae; phallotremal sclerite small, U-shaped in dorsal view.

\section{Material examined}

Holotype.—ô: COSTA RICA. Alajuela: R. Agrio, 3.5 km NE Bajos del Toro, $10.243^{\circ} \mathrm{N}, 84.279^{\circ} \mathrm{W}$, el. 1290 m, 20.viii.1990, Holzenthal et al. (NMNH).

Paratypes.-COSTA RICA. Alajuela: Cerro Campana, R. Bochinche trib., $6 \mathrm{~km}$ (air) NW Dos Ríos, $10.945^{\circ} \mathrm{N}, 85.413^{\circ} \mathrm{W}$, el. $600 \mathrm{~m}, 22-23 . v i i .1987$, Holzenthal, Morse, Clausen, $1 \hat{o}$ (UMSP); Puntarenas: $R$. Bellavista, $\sim 1.5 \mathrm{~km}$ NW Las Alturas, $8.951^{\circ} \mathrm{N}, 82.846^{\circ} \mathrm{W}$, el. 1400 m, 8-9.iv.1987, Holzenthal, Hamilton, Heyn, 10ิ (UMSP).

\section{Etymology}

The specific epithet refers to the distinctive large bulging eyes of this species.

\section{Nectopsyche gemmoides Flint}

Figs. 1-5, 16

Nectopsyche gemmoides Flint 1981:35, figs. 156, 157, 169 [Type locality: Venezuela, Aragua, Maracay, Río Limón, Estación Pisicultura; $\mathrm{NMNH} ; \boldsymbol{\jmath}]$.

\section{Diagnosis}

This is the only species with no trace of silver scales on the head or thorax and one of only two species with no silver stripes basally on the forewing. Otherwise, it is most similar to $N$. utleyorum n. sp. in coloration, especially in the transverse wing bands at the middle of the wing and the punctation and bands at the wing apex. However, the bands in the middle of the wing are usually narrower in $N$. gemmoides than in N. utleyorum n. sp., and converge toward each other (especially in specimens from Venezuela). Also, N. gemmoides always has a small dash of black scales anterior of the apical-most of the four large black spots along Cu1b and the apical-most wing bands are narrow, extend almost across the wing width, and almost never having fuscous hairs bordering them. In N. utleyorum n. sp., I have seen the black dash in only one male and a few female specimens and the apical wing bands are wider, constricted mesally, and always have the silver scales bordered by fuscous hairs. The genitalia of the two species are similar, but $N$. gemmoides has thin, but distinct periphallic processes, while these processes are completely lacking in N. utleyorum n. sp.

\section{Description}

Adult (Fig. 16).-Forewing length $8.5 \mathrm{~mm}\left({ }^{\prime}\right)$, $6.5 \mathrm{~mm}$ (\$). Head straw colored, covered with yellow hairs, without white scales and hairs adjacent to eyes or on vertex or antennal scapes. Eyes small. Thorax straw colored, covered with yellow and golden hairs, without white scales or hairs; legs straw colored. Forewings covered with golden-yellow hairs. Base of each forewing without patches or stripes of white or silver scales, but with small patch of fuscous hairs near crook in M. Middle of forewing with two broad transverse bands of silver scales bordered by fuscous hairs, both bands narrowing along their lengths (narrow throughout in some individuals), converging toward each other (fusing posteriorly in ôs from Venezuela, but more 
parallel in is from across range), and extending across width of wing. Four large spots of black scales along $\mathrm{Cu} 1 \mathrm{~b}$, these set in silver scales posteriorly and laterally, and with oval patch of white scales anteriorly, basal-most black spot U-shaped, remaining spots roughly figure-8 shaped, each connected by narrow longitudinal stripe of black scales, with diagnostic dash of black scales anterior of apical spot; cord with row of 2-3 small silver spots posterior of large oval silver spot, the latter bordered by fuscous hairs and with small patch of fuscous hairs at crossvein $r$; three transverse apical wing bands: basal-most band often broken, white anteriorly, silver posteriorly; middle band narrow, mostly silver, the silver occasionally bordered by some fuscous hairs, and extending almost across width of wing; apical-most band silver, narrow, faint, often absent.

Male genitalia (Fig. 1).-Abdominal segment IX narrow laterally; tergum shallow, somewhat produced posteriorly. Preanal appendages long, setose, forked apically, each with apicoventral fork long, thin, blade-like, lacking setae and distinctly demarcated from body of preanal appendage. Segment $X$ lateral processes thin, narrow, their apices somewhat truncate, bearing small subapical setae. Inferior appendages broad basally, rounded apically, with numerous long setae; each with apicomesal lobe rounded apically; basoventral process broad, about as long as wide. Phallic apparatus with periphallic processes, very thin, their apices not enlarged; endothecal membranes highly erectile, bearing about 2-4 spine-like setae; phallotremal sclerite indistinct.

\section{Material examined}

COSTA RICA. Guanacaste: Parque Nacional Guanacaste, El Hacha, Q. Alcornoque, $11.009^{\circ} \mathrm{N}, 85.577^{\circ} \mathrm{W}$, el. $250 \mathrm{~m}$, 26.vii.1987, Holzenthal, Morse, Clausen, $19 \hat{\circ}, 7$ ㅇ (UMSP); same, except Q. Pedregal, $10.983^{\circ} \mathrm{N}$, $85.539^{\circ} \mathrm{W}$, el. $300 \mathrm{~m}, 27 . v i i .1987$, Holzenthal, Morse, Clausen, $4 \hat{\delta}, 3$ (UMSP); same, except Maritza, R. Tempisquito, $10.958^{\circ} \mathrm{N}, 85.497^{\circ} \mathrm{W}$, el. $550 \mathrm{~m}, 19-20 . v i i .1987$, Holzenthal, Morse, Clausen, 10 (UMSP); same, except 30-31.viii.1990, Huisman, Blahnik, Quesada, 19 (UMSP); Parque Nacional Santa Rosa, R. Cuajiniquil, $10.881^{\circ} \mathrm{N}, 85.613^{\circ} \mathrm{W}$, el. $250 \mathrm{~m}$, 25.vii.1987, Holzenthal, Morse, Clausen, 39 (UMSP); same, except Q. San Emilio, $10.862^{\circ} \mathrm{N}, 85.610^{\circ} \mathrm{W}$, el. $300 \mathrm{~m}, 27 . v i .1986$, Holzenthal, Heyn, Armitage, $10^{\wedge}$ (UMSP); R. Tizate, 7.2 $\mathrm{km}$ NE Cañas Dulces, $10.773^{\circ} \mathrm{N}, 85.449^{\circ} \mathrm{W}$, el. $275 \mathrm{~m}$, 28.vi.1986, Holzenthal, Heyn, Armitage, 5 ㅇ (UMSP); Heredia: Est. Biol. La Selva, Q. El Salto, $10.427^{\circ} \mathrm{N}$, $84.005^{\circ} \mathrm{W}$, el. $50 \mathrm{~m}, 10 . \mathrm{ii} .1986$, Holzenthal, 1ठ, 39 (UMSP); same, except R. Puerto Viejo, $10.440^{\circ} \mathrm{N}$, 84.012 ${ }^{\circ} \mathrm{W}$, el. $30 \mathrm{~m}, 10-11 . i i .1986$, Holzenthal, 1ô, 1 \% (UMSP); P. N. Braulio Carrillo, Est. El Ceibo, R. Peje, $10.327^{\circ} \mathrm{N}, 84.078^{\circ} \mathrm{W}$, el. $480 \mathrm{~m}$, Holzenthal, Blahnik, Muñoz, 1o, 2 o (UMSP); Limón: Reserva Biol. HitoyCerere, R. Cerere, $9.671^{\circ} \mathrm{N}, 83.028^{\circ} \mathrm{W}$, el. $90 \mathrm{~m}, 23-$ 24.iii.1987, Holzenthal, Hamilton, Heyn, 60, 29 (UMSP); R. Uatsi, $\sim 8 \mathrm{~km}$ (air) $\mathrm{W}$ Bribri, $9.62^{\circ} \mathrm{N}$, $82.90^{\circ} \mathrm{W}$, el. $60 \mathrm{~m}, 25$. iii.1987, Holzenthal, Hamilton, Heyn, 10 (UMSP); Cariari, R. Tortuguero, 24.iv.1984, Barrera, 19 (IBUNAM); Puntarenas: Parque Nacional Corcovado, R. Clara, $1.5 \mathrm{~km}$ SE Sirena, $8.472^{\circ} \mathrm{N}$, $83.588^{\circ} \mathrm{W}$, el. $15 \mathrm{~m}, 8 . i v .1989$, Holzenthal, 4 \% , 1 \% (UMSP); same, except Estación Sirena, 5-7.ii.1981, Bueno, 10, 99 (IBUNAM); R. Rincón, 6.5 km (air) S Rincón, $8.638^{\circ} \mathrm{N}, 83.480^{\circ} \mathrm{W}$, el. $20 \mathrm{~m}$, 7.iv.1987, Holzenthal, Hamilton, Heyn, 4ồ (UMSP); San José: Res. Biol. Carara, R. Carara, $4.3 \mathrm{~km}$ (rd.) E Costanera Sur, $9.810^{\circ} \mathrm{N}, 84.572^{\circ} \mathrm{W}$, el. $20 \mathrm{~m}, 12 . i i i .1991$, Holzenthal, Muñoz, Huisman, 2o (UMSP); same, except R. del Sur, $1.5 \mathrm{~km}$ (rd.) S of Carara, $9.769^{\circ} \mathrm{N}, 84.531^{\circ} \mathrm{W}$, el. $160 \mathrm{~m}$, 13.iii.1991, Holzenthal, Muñoz, Huisman, 20, 19 (UMSP). MEXICO. Chiapas: Bonampak, 20.v.1984, Garcia 2 $\delta$ (IBUNAM); same, except Ibarra, 1o (IBUNAM); same, except 20-25.v.1980, Bueno, 8ㅇ, 4ㅇ (IBUNAM); Cascada Misolha, $20 \mathrm{~km}$ from Palenque, 18.v.1981, Bueno, 11ð, 19 (IBUNAM); same, except Velasco, 3ô (IBUNAM); Ejido, Sta. Elena $50 \mathrm{~km}$ beyond L. Montebello, Bueno, 7.iv.1979, 2o (IBUNAM); Km 305, R. Izapa, 21.iv.1983, Bueno, 4ô (IBUNAM); Palenque, 19.v.1984, Garcia, 1o (IBUNAM); Palenque, Nututun, 20.vii.1978, Bueno, 9o (IBUNAM); R. Chacamax, Bal. Nututun, 7.xii.1975, Bueno, 2 ? (IBUNAM); R. Contento, $7 \mathrm{~km}$ Ocosingo, 20.v.1981, Bueno, Velasco, $2 \delta$ (IBUNAM); R. Nututun, 31.i.1985, Velasco, $1 \delta$ (IBUNAM); R. Tulijá $40 \mathrm{~km}$ from Palenque, 17.v.1981, Bueno, 2ô, 2o; same, except Velasco, 2î, $3 \%$ (IBUNAM); Oaxaca: Bethania, R. Coapan, 24.v.1981,

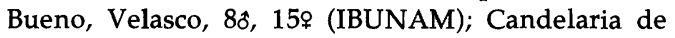
Loxicha, 10.ii.1982, Garcia, 9o (IBUNAM); Jacatepec, 4.vii.1979, Padilla, 1 ( (IBUNAM); Reserva Montes Azules, 14.vii.1987, Arias, 2ठ (IBUNAM); same, except Barba, 4ô (IBUNAM); same, except Cervantes, $1 \hat{}$ (IBUNAM); Uxpanapa, 27.ix.1977, Bueno, 8ठ (IBUNAM); Veracruz: Balsapote, 18.ii.1977, Bueno, 1o (IBUNAM); Ocatal Chico, S Sta. Martha, Los Tuxtlas, 24-26.i.1981, Perez, 19 (IBUNAM); Los Tuxtlas, Puente La Palma, 17.vii.1977, Bueno, 5ㅇ (IBUNAM); same, except Río Las Palmas, 30.xi.1977, Gonzales, 10 (IBUNAM); same, except 5.v.1981, 1 \% (IBUNAM); same, except 7.v.1981, Hernandez, 19 (IBUNAM); same, except R. Máquinas, 4.v.1981, 1ô (IBUNAM). PERU. Madre De Dios: Manu, Pakitza, (12\%7'S, 70 $\left.58^{\prime} \mathrm{W}\right)$, el. $250 \mathrm{~m}$, 9-23.ix.1988, Flint, Adams, $2 \delta^{\circ}$ (NMNH); same, except trail 1, 1st stream, 11.ix.1988, 1ㅇ, 9ㅇ (NMNH); same, 
except trail 2, 1st stream, 17-20.ix.1988, 1ㅇ (NMNH); same, except trail 1, 1st stream, 20.ix.1988, Pogue, 5o, 2o (NMNH); same, except R. Manu, 9-21.ix.1988, Flint, Adams, 6ô, 1ㅇ (NMNH); same, except R. Manu, Limonal (10 km N Boca Manu), el. $200 \mathrm{~m}, 7 . i x .1988,10$ (NMNH). VENEZUELA. Aragua: R. El Limón, fish hatchery, Maracay, 3-6.ii.1976, C. \& O. Flint, 2ô paratypes (NMNH); Guárico: Hato Masaguaral, $45 \mathrm{~km} \mathrm{~S}$ Calabozo, $8.57^{\circ} \mathrm{N}, 67.58^{\circ} \mathrm{W}$, Gal'ry Forest, \#20, $75 \mathrm{~m}$, 13-16.iv.1988, Epstein, Blahnik, 6\$, 10 (UMSP); same, except Gal'ry Forest, \#4, 12-13.iv.1988, 3 ㅇ (UMSP).

\section{Nectopsyche monticola new species} Figs. 8, 17

\section{Diagnosis}

This new species shares with $N$. gemmoides the lack of basal wing stripes and with $N$. tapanti $\mathrm{n}$. sp. the pattern of black spots along $\mathrm{Cu} \mathrm{lb}$, but is otherwise very different from those species. A color character that renders $N$. monticola unique is the broad borders of brown hairs around all transverse wing bands and spots. Diagnostic features of the genitalia include the shallowly forked preanal appendages (similar to those of N. exophthalma) and the digitate basoventral processes of the inferior appendages.

\section{Description}

Adult (Fig. 17)._Forewing length $10 \mathrm{~mm}(\hat{\delta})$, $9 \mathrm{~mm}($ ( ). Head straw colored, covered with yellow hairs, dorsally with small patch of white scales and hairs bordering eyes and with small white patch on vertex; antennal scapes yellow; antennal flagellomeres yellowish white. Eyes small. Thorax straw colored, covered with yellow and golden hairs; mesoscutum with area of white scales laterally; legs straw colored. Forewings covered with golden-brown hairs. Base of each forewing without patches or stripes of white or silver scales, but with small patch of brown hairs near crook in $\mathrm{M}$. Middle of forewing with two narrow transverse bands of silver scales broadly bordered by brown hairs: basal band slightly broken, widely separated from apical band. Series of small spots of black scales along $\mathrm{Cu} 1 \mathrm{~b}$, these not set in silver scales, except around the two basal spots, and with only faint, diffuse oval area of cream colored hairs anteriorly; basal-most black spot small, oval, situated basad of tilted Y-shaped line of black scales along the vein, with two small oval black spots posterior of the stalk and one anterior; cord with series of diffuse, irregular white spots, broadly bordered with brown hairs; three narrow, transverse, apical wing bands: basal band extending across width of wing, but broken at midlength; middle and apical bands shorter; all bands broadly bordered by brown hairs.

Male genitalia (Fig. 8).-Abdominal segment IX broad laterally; tergum broad, rounded, somewhat produced posteriorly. Preanal appendages long, setose, each slightly forked apically. Segment $X$ lateral processes thin, narrow, their apices narrow, pointed, bearing small subapical setae. Inferior appendages equally broad throughout length; rounded apically, each with very slight subapicodorsal setose projection; apicomesal lobe narrow, truncate apically, with long setae near gap where apicomesal lobe originates from body of inferior appendage; basoventral process narrow, digitate. Phallic apparatus with distinct periphallic processes, each slightly enlarged and pointed apically; endothecal membranes highly erectile, bearing about 8-12 spine-like setae; phallotremal sclerite small, U-shaped in dorsal view.

\section{Material examined}

Holotype.-ô: COSTA RICA. San José: Q. Muerte, Rt. 2, $3.5 \mathrm{~km}$ (air) W Villa Mills, $9.562^{\circ} \mathrm{N}, 83.743^{\circ} \mathrm{W}$, el. 3120 m, 7.viii.1990, Holzenthal, Blahnik, Muñoz (NMNH).

Paratypes.-Same data as holotype, 29 (UMSP), 19 (INBIO).

\section{Etymology}

Monticola refers to the tropical montane rain forest habitat of the type locality near Cerro de la Muerte, Costa Rica.

\section{Nectopsyche onyx new species} Figs. 9, 18

\section{Diagnosis}

This is the smallest species of those I have seen in the group. The presence of a third transverse band in the middle of the wing renders the species distinct, as does the perpendicular nature of all three of these bands. The genitalia of the species are very similar to those of $N$. utleyorum n. sp. (e.g., both lack or have vestigial 

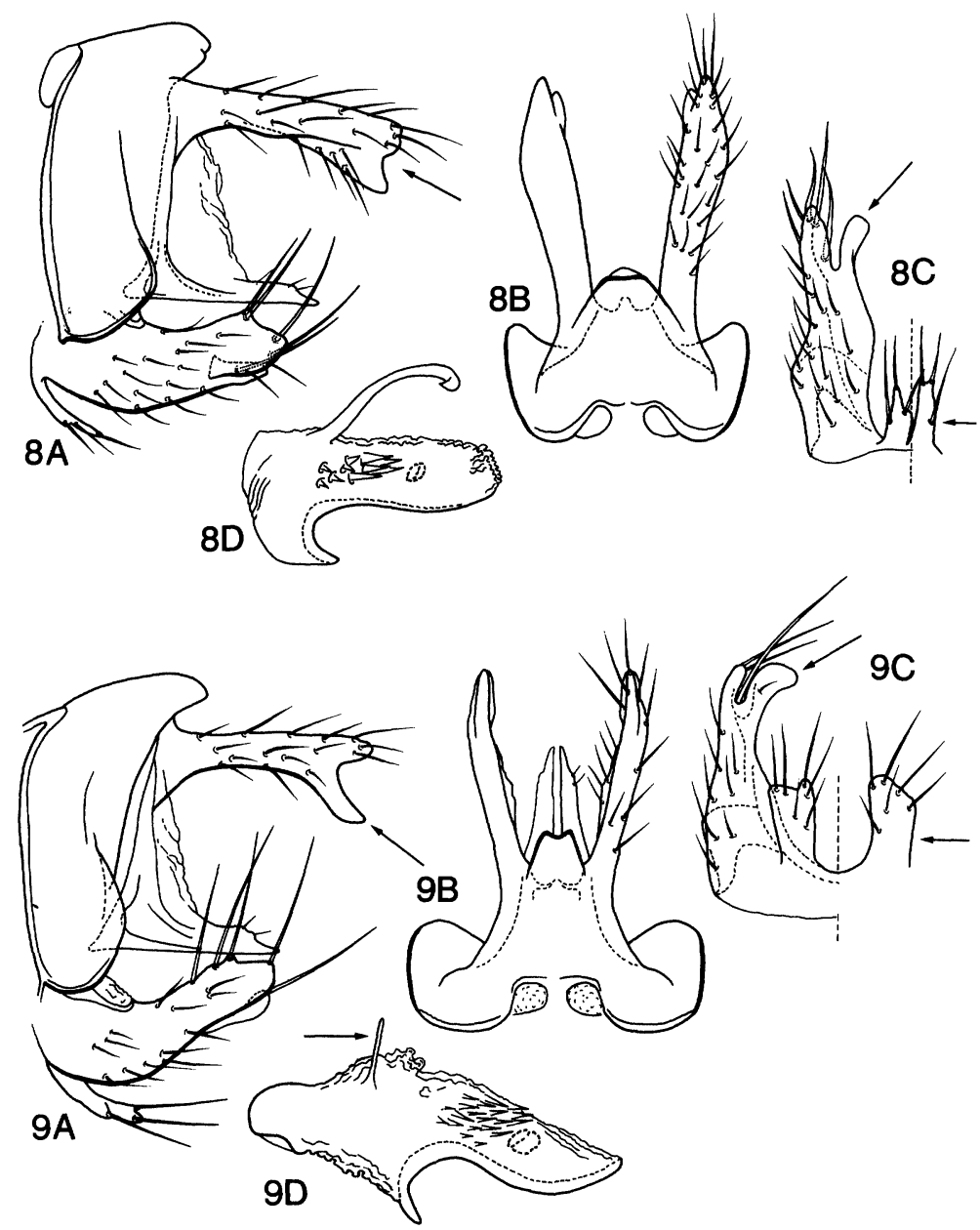

FIGs. 8, 9. Nectopsyche spp., male genitalia. 8. -N. monticola new species. 9.-N. ony $x$ new species. Structures and orientations are the same as those in Fig. 1, A-D. Arrows highlight important diagnostic features discussed in the text.

periphallic processes, have wide basoventral processes and similarly shaped apicomesal lobes of the inferior appendages).

\section{Description}

Adult (Fig. 18).-Forewing length $6.5 \mathrm{~mm}(\hat{\jmath})$, $5 \mathrm{~mm}$ (q). Head straw colored, covered with yellow hairs, dorsally with white scales and hairs bordering eyes and with white patch on vertex; antennal scape yellow; antennal flagellomeres yellowish white. Eyes small. Thorax straw colored, covered with yellow and golden hairs; mesoscutum with elongate stripe of white scales laterally; legs straw colored. Forewings covered with golden-yellow hairs. Base of each forewing without longitudinal stripes of silver scales except between $C$ and Sc. Middle of forewing with three broad, perpendicular transverse bands of silver scales bordered by fuscous hairs, basal band short, middle and apical bands extending across width of wing and uniformly wide throughout their lengths. Large spots of black scales along $\mathrm{Cu} 1 \mathrm{~b}$, these set in silver scales posteriorly and laterally and with reniform patch of white scales anteriorly, basal-most black spot hourglass-shaped, remaining spots large, shaped as in Fig. 18B, each connected by broad longitudinal stripe of black scales; diffuse patch of black scales anterior of apical spot; cord with only single large oval silver spot bordered by fuscous hairs ( 9 paratypes from Corcovado and Carara with area around oval spot and pterostigma covered with fuscous scales); two trans- 
verse apical wing bands: basal band broken, white anteriorly, silver posteriorly; apical band broader, constricted at middle, white anteriorly, silver posteriorly, the silver bordered by fuscous hairs.

Male genitalia (Fig. 9).-Abdominal segment IX broad laterally; tergum broad, rounded, somewhat produced posteriorly. Preanal appendages long, setose, forked apically, each with apicoventral fork long, thin, without setae. Segment $X$ lateral processes thin, narrow, their apices pointed, bearing small subapical setae. Inferior appendages broad basally, rounded apically, with numerous long setae; each with apicomesal lobe rounded apically, turned mesally, with long setae near gap where apicomesal lobe originates from body of inferior appendage; basoventral process broad, elongate. Phallic apparatus with periphallic processes short, vestigial or absent; endothecal membranes highly erectile, bearing about 10 20 spine-like setae; phallotremal sclerite small, U-shaped in dorsal view.

\section{Material examined}

Holotype.-ô: COSTA RICA. Puntarenas: Parque Nacional Corcovado, Piedra el Arco, $8.582^{\circ} \mathrm{N}, 83.709^{\circ} \mathrm{W}$, el. $20 \mathrm{~m}, 10-11 . i v .1989$, Holzenthal, Blahnik (NMNH).

Paratypes.-Same data as holotype, 10, 2 (UMSP) COSTA RICA. Puntarenas: Reserva Biológica Carara, Q. Bonita, $9.775^{\circ} \mathrm{N}, 84.605^{\circ} \mathrm{W}$, el. $34 \mathrm{~m}$, Holzenthal, Blahnik, 19 (INBIO); trib. to R. Bellavista in Las Alturas (road to quarry), $8.952^{\circ} \mathrm{N}, 82.846^{\circ} \mathrm{W}$, el. $1480 \mathrm{~m}$, 19.iii.1991, Holzenthal, Muñoz, Huisman, 19 (UMSP).

\section{Etymology}

Onyx, a yellowish gem stone, refers to the gemlike appearance of this species and others in the gemma group.

\section{Nectopsyche ortizi new species}

Figs. 10, 19

Nectopsyche gemma Flint 1974a:129, fig. 274, pl. 4A, nec Müller 1880.

\section{Diagnosis}

This widespread species was long considered to be N. gemma (Müller) (e.g., Flint 1974a), the type species of the genus, until Flint (1991) des- ignated a neotype for N. gemma from material collected by Fritz Müller in Santa Catarina, Brazil, thus stabilizing the taxonomy. It is very different in aspects of coloration and genitalia from both the type species and others in the gemma group. In coloration, the stripes on the head and thorax of the new species are narrower, more numerous, and composed of white, rather than silver scales. The mesal wing bands are wider, perpendicular, and much more iridescent than in other species. The male genitalia are also totally different. In N. ortizi, segment IX, the preanal appendages and inferior appendages are all very narrow, not broad as they characteristically are in other gemma group species. The preanal appendages are blunt, with no trace of an apical fork. The apicomesal lobe of the inferior appendage is very broad and plate-like, unlike that in any other species. Finally, tergum IX is not produced posteriorly, and is excavated mesally. It is certainly the most atypical member of the gemma group thus far described.

\section{Description}

Adult (Fig. 19).-Forewing length $10.5 \mathrm{~mm}$ (o), $8.5 \mathrm{~mm}$ (क). Head straw colored, covered with yellow hairs, dorsally with line of white scales bordering eyes, median white line on vertex, and small white patches laterally before and behind eyes; antennal scapes yellow, with narrow lateral and mesal stripes of white scales; antennal flagellomeres yellow, each with basal ring of white hairs. Eyes small. Thorax straw colored, covered with yellow and golden hairs; mesoscutum with elongate stripes of white scales laterally and mesally, small patch of white scales on mesoscutellum; legs straw colored. Forewings covered with golden-yellow hairs. Base of each forewing with series of six stripes of white scales, each bordered by fuscous hairs, along major longitudinal veins between jugum and basal costal border as illustrated in Fig. 19B (in the paratypes from Misiones, Argentina, the third stripe from the costal border is oval). Middle of forewing with two broad, perpendicular transverse bands of highly iridescent silver scales bordered by light brown hairs, each band more or less uniformly wide throughout length and extending across width of wing. Four small spots of black scales along $\mathrm{Cu} 1 \mathrm{~b}$, these set in silver scales mesally and laterally and with oval patch of white scales anteriorly, each spot 


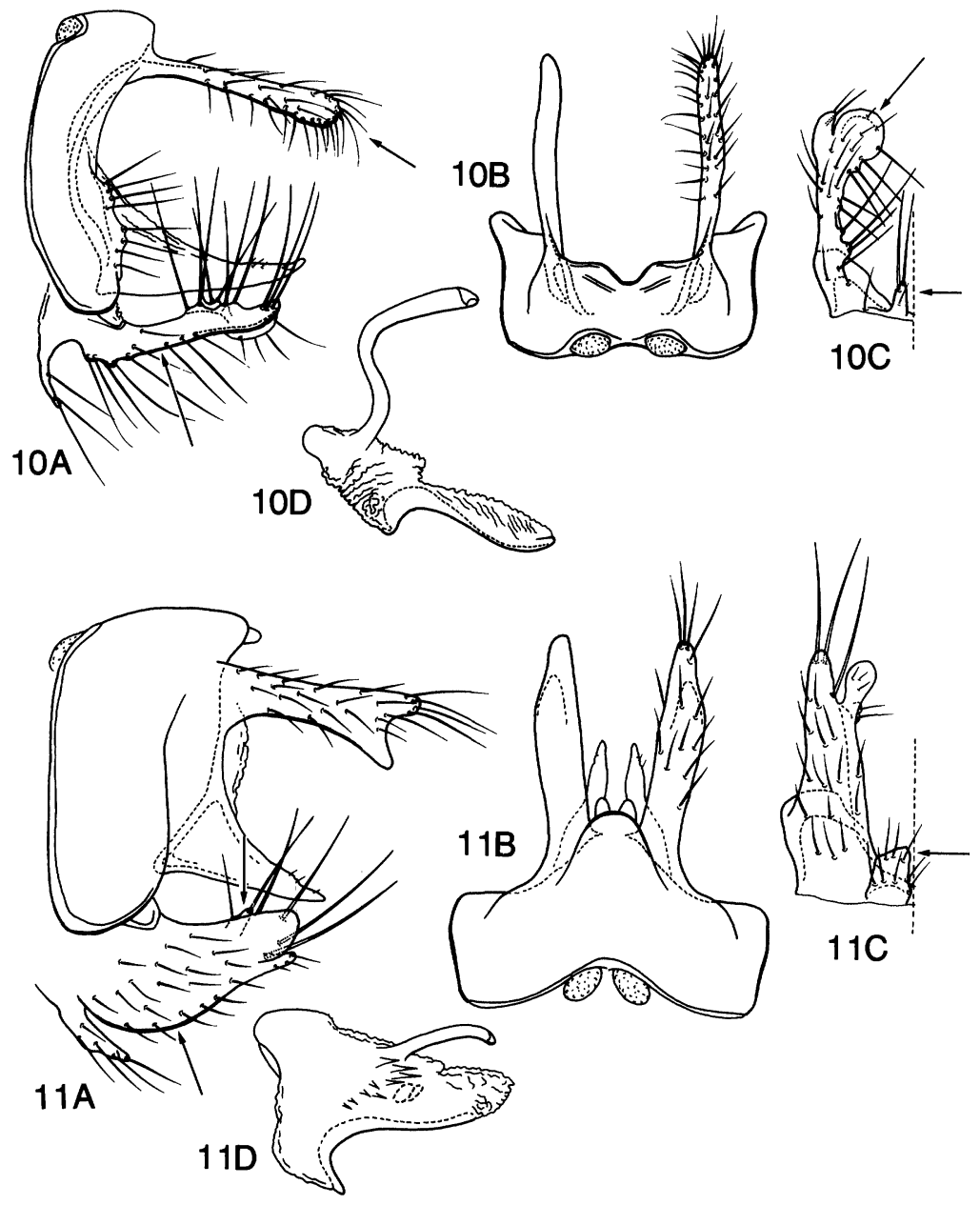

Figs. 10, 11. Nectopsyche spp., male genitalia. 10.-N. ortizi new species. 11. - N. tapanti new species. Structures and orientations are the same as those in Fig. 1, A-D. Arrows highlight important diagnostic features discussed in the text.

roughly figure-8 shaped; cord with series of oval silver spots bordered by light brown hairs, smaller white spots, and semicircular white spot at apex of Sc (punctation as illustrated in Fig. 19B); two transverse apical wing bands: basal band often broken into two elongate silver spots, apical band shorter, silver, each band bordered by fuscous hairs.

Male genitalia (Fig. 10).-Abdominal segment IX very narrow laterally, with long setae basolaterally; tergum narrow, excavated mesally, not produced posteriorly. Preanal appendages long, setose, blunt apically. Segment $X$ lateral processes thin, narrowly tapered through their length, apices pointed, bearing small subapical setae. Inferior appendages very narrow, straight, with prominent elongate setae, especially dorsally; each with apicomesal lobe very broad, flat, rounded; basoventral process short, digitate. Phallic apparatus with distinct periphallic processes, slightly enlarged and pointed apically; endothecal membranes highly erectile, without spine-like setae; phallotremal sclerite indistinct.

\section{Material examined}

Holotype.-ô: COSTA RICA. Limón: P. N. Tortuguero, R. Tortuguero, $3.5 \mathrm{~km} \mathrm{~S}$ Tortuguero, $10.509^{\circ} \mathrm{N}$, 
83.504 $\mathrm{W}$, el. $5 \mathrm{~m}$, 4.iv.1989, Holzenthal, Blahnik (NMNH).

Paratypes.-ARGENTINA. Chaco: Rcho. Barranqueras, Pto. Vilelas, 5.xii.1973, Flint, 1ㅇ (NMNH); Entre Rios: Ao. P. Verne, 4 km No Va. San José, 15.xi.1973, Flint, 19 (NMNH); Misiones: Ao. Piray Guazú, No. San Pedro, 22.xi.1973, Flint, 6ô, 2o (NMNH); Ao. Piray Mini, W Dos Hermanas, 23.xi.1973, Flint, 20, 4 우 (NMNH); Pto. Libertad, 24.xi.1973, Flint, 19 (NMNH); R. Iguazu, Camp. Nandu, 25.xi.1973, Flint, 1ô, 2 o (NMNH). BRAZIL. Para: R. Xingu, Camp, $52^{\circ} 22^{\prime} \mathrm{W}$, $3^{\circ} 39^{\prime}$ S, $\sim 60 \mathrm{~km}$ S Altamira, 8-12.x.1986, Spangler, Flint, 1 ( $\mathrm{NMNH}$. COSTA RICA. same data as holotype, 1ô (UMSP); Guanacaste: R. Mena, $4.2 \mathrm{~km} \mathrm{~W}$ Santa Cecilia, $11.059^{\circ} \mathrm{N}, 85.448^{\circ} \mathrm{W}$, el. $260 \mathrm{~m}$, 11.iii.1986, Holzenthal, Fasth, 1 (ㄴ) (USP); Heredia: Est. Bio. La Selva, Q. Sura, $10.437^{\circ} \mathrm{N}, 84.101^{\circ} \mathrm{W}$, el. $50 \mathrm{~m}, 20-21 . v i .1986$, Holzenthal, Heyn, Armitage, 1 ( (UMSP); same, except, R. Puerto Viejo, $10.440^{\circ} \mathrm{N}, 84.012^{\circ} \mathrm{W}$, el. $30 \mathrm{~m}$,

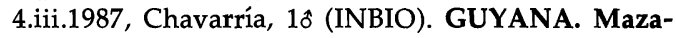
runi-Potaro: Takutu Lumber Camp, Takutu Mountains, $6.25^{\circ} \mathrm{N}, 59.0^{\circ} \mathrm{W}, 29 . x i 1.1982$, Steiner, Lowry, Williams, 29 (NMNH); Takutu Mountains, $6^{\circ} 15^{\prime} \mathrm{N}, 59^{\circ} 5^{\prime} \mathrm{W}$, 15.xii.1983, Spangler, Steiner, 10, 19 (NMNH); same, except 5.xii.1983, 1 (NMNH); same, except 8.xii.1983, 1 ( $(\mathrm{NMNH})$; same, except 9.xii.1983, 1 ( $(\mathrm{NMNH})$; same, except 14.xii.1983, 19 (NMNH); same, except 19.xii.1983, 19 (NMNH). MEXICO. Chiapas: Bonampak, 20-25.v.1980, Bueno, 10, 2 (IBUNAM); Reserva Montes Azules, 13.vii.1987, Barba, 2 2 (IBUNAM); Oaxaca: Ao. Choapan, Bethania, $31 \mathrm{~km} \mathrm{~S}$ Tuxtepec, 24.v.1981, C. \& O. Flint, 1 ( $(\mathrm{NMNH})$. PANAMA. R. Trinidad, 12.iii, Busck, 1 ( $(\mathrm{NMNH})$; same, except 12.vi, 1ô, $1 \%$ (NMNH). PARAGUAY. R. Aquidaban, Cerro Cora, 29.xi.1973, Flint, 1ô (NMNH); Ao. Tapiracuay, San Estanislao, 27.xi.1973, Flint, $1 \hat{\jmath}(\mathrm{NMNH}) ; 3.9 \mathrm{~km}$ south Villarica, 2.xii.1972, Flint, 4ㅇ (NMNH); Sacupay, 24.xi.1971, Peña G., 19 (NMNH). PERU. Iquitos, 27.vii.-7.viii.1920, Cornell Univ. Expedition, Lot 569, 1o (NMNH). SURINAM. Blanche Marie, 12.ii.1971, Geijskes, 1ㅇ (NMNH); same, except 14.ii.1971, $1 \hat{\delta}$ (NMNH); Moengo, above Cottica R., Cornell Univ. Lot 760 Sub 62, 17.v.1927, 19 (NMNH). VENEZUELA. Cojedas: Galeras del Pao, 29.vii.1967, Rosales, Poole, 39 (IZAM); Guárico: Hato Masaguaral, $45 \mathrm{~km} \mathrm{~S} \mathrm{Cal-}$ abozo, Savanna \#15, $8.57^{\circ} \mathrm{N}, 67.58^{\circ} \mathrm{W}$, el. $75 \mathrm{~m}, 6-$ 8.v.1988, Epstein, Blahnik, 1ô (UMSP); Bolivar: Morichal Tauca, $22 \mathrm{~km}$ E R. Caura, 8-9.ii.1976, C. \& O. Flint, 29 (NMNH); Anacoco, 6 $6^{\circ} 5^{\prime} \mathrm{N}, 61^{\circ} 8^{\prime} \mathrm{W}, 60 \mathrm{~m}, 10$ 30.viii.1979, Expedición La Salle, 2̇, 2 (IZAM).

\section{Etymology}

Named in honor of Professor Rodolfo Ortiz Vargas, Universidad de Costa Rica, San Ramón, in recogniton of his many contributions to the study and preservation of Costa Rican natural history, especially that of the Reserva Forestal San Ramón.

\section{Nectopsyche tapanti new species Figs. 11, 20}

\section{Diagnosis}

Nectopsyche tapanti, like $N$. argentata, N. exophthalma, and N. utleyorum n. sp., can be recognized by the longitudinal silver stripes on the base of the forewing. Unlike the other striped species, the major silver basal stripe is broader in N. tapanti. Also, the basal-most of the broad transverse bands at the middle of the wing is short and much tilted apicad; in the other species this band is longer and not as slanted. The black punctation along $\mathrm{Culb}$ is similar to that of $N$. monticola, but the apical wing bands differ between these species and those mentioned above. In $N$. tapanti, the apex of the wing is dominated by a broad, mostly white band, bordered by fuscous hairs, and tilted basad. In the other species, this band is narrower, mostly silver, and perpendicular or tilted slightly apicad. The genitalia of the new species have inferior appendages that are broader than those of the above mentioned species, but are otherwise typical of the gemma group ground plan.

\section{Description}

Adult (Fig. 20).-Forewing length $9.5 \mathrm{~mm}$ ( $(\delta)$, $8 \mathrm{~mm}$ (?). Head straw colored, covered with yellow hairs, dorsally with white scales and hairs bordering eyes and with white patch on vertex; antennal scapes yellow with narrow lateral and mesal stripes of white scales; antennal flagellomeres yellowish white, each with basal ring of white hairs. Eyes small. Thorax straw colored, covered with yellow and golden hairs; mesoscutum with elongate patch of white scales laterally; legs straw colored. Forewings covered with golden-yellow hairs. Base of each forewing with long, wide stripe of silver scales along base of $\mathrm{A} 1+\mathrm{A} 2$ and silver scales between $\mathrm{C}$ and Sc extending to basal-most transverse band. Middle of forewing with two broad transverse bands of silver scales bordered anteriorly by fuscous hairs: basal band highly tilted apicad, extending from $C$ to about stem of $M$, narrow- 
ing along its length; apical band extending across width of wing, very broad at $C$, narrowing toward anal margin. Small spots of black scales along $\mathrm{Cu} 1 \mathrm{~b}$, these set in silver scales, with small oval patch of white scales anteriorly and band of silver scales apically; basal-most black spot small, comma-shaped, then three spots posteriorly and two spots anteriorly of T-shaped narrow longitudinal stripe of black scales; cord with single small oval spot of silver scales; patch of diffuse fuscous hairs at apex of Sc; two transverse apical wing bands: basal band broken, white anteriorly, silver posteriorly; apical band broader, tilted basad, white for more than half its length, silver posteriorly, bordered by fuscous hairs.

Male genitalia (Fig. 11).-Abdominal segment IX broad laterally; tergum broad, rounded, somewhat produced posteriorly. Preanal appendages long, setose, forked apically. Segment $X$ lateral processes thin, narrow, their apices pointed, bearing small subapical setae. Inferior appendages broad basally, narrowing apically; each with apex rounded and with subapicodorsal setose projection; apicomesal lobe rounded apically, with long setae near gap where apicomesal lobe originates from body of inferior appendage; basoventral process short, quadrate. Phallic apparatus with distinct, but short periphallic processes, these pointed apically; endothecal membranes highly erectile, bearing about $8-10$ spine-like setae; phallotremal sclerite indistinct.

\section{Material examined}

Holotype.-ô: COSTA RICA. Cartago: Reserva Tapantí, Q. Palmitos and falls, $9.72^{\circ} \mathrm{N}, 83.78^{\circ} \mathrm{W}$, el. 1400 m, 2-3.vi.1990, Holzenthal, Blahnik, Muñoz (NMNH).

Paratypes.-COSTA RICA. Same data as holotype, 9ô, 5 o (UMSP); Reserva Tapantí, R. Grande de Orosi, 9.686 ${ }^{\circ} \mathrm{N}, 83.756^{\circ} \mathrm{W}$, el. $1650 \mathrm{~m}, 8-9 . v i i .1986$, Holzenthal, Heyn, Armitage, 10 (INBIO); same, except 78.vi.1988, C. \& O. Flint, Holzenthal, 1 ( $(\mathrm{NMNH})$; same, except unnamed tribs., $\sim 9 \mathrm{~km}$ (road) NW tunnel, $9.72^{\circ} \mathrm{N}, 83.78^{\circ} \mathrm{W}, 8-9 . v i i .1988$, C. \& O. Flint, Holzenthal, 10,1 우 (NMNH).

\section{Etymology}

Named for the type locality, the Tapantí Wildlife Reserve in the Talamanca Mountains of Costa Rica, an area rich in endemic caddisflies species.

\section{Nectopsyche tuanis new species}

Fig. 12, 21

\section{Diagnosis}

This striking species is unlike any described species in the genus in terms of coloration. The dark color of the wings, the arrangement of the transverse bands, and the punctation of the cord are all diagnostic. Its genitalia, too, are diagnostic, especially the broad inferior appendages and the narrow lateral processes of segment $X$.

\section{Description}

Adult (Fig. 21).-Forewing length $9 \mathrm{~mm}(\hat{\imath})$, $7 \mathrm{~mm}$ (\$). Head brown, covered with yellow hairs, dorsally with white scales and hairs bordering eyes and with white patch on vertex; antennal scapes brown with lateral and mesal stripes of white scales; antennal flagellomeres brown, each with wide basal ring of white hairs. Eyes small. Thorax fuscous, covered with yellow and golden hairs; mesoscutum with elongate patch of white scales laterally; legs light brown. Forewings covered with golden-yellow hairs apically and in anal region, but most of wings covered with brown hairs. Base of each forewing with patch of white scales on jugum, long wide stripe of white scales along base of $\mathrm{Al}+\mathrm{A} 2$, shorter, stripe of silver scales at midlength of Sc, highly tilted apicad. Middle of forewing with two broad transverse bands of silver scales: basal-most band strongly arched basad and extending from $\mathrm{C}$ to $\mathrm{A} 1+\mathrm{A} 2$ where it joins basal longitudinal white band; apicalmost band extending across width of wing, but broken near base of discal cell and slanted basad, scales near anal margin white. Black and silver scales along $\mathrm{Cu} 1 \mathrm{~b}$, these bordered apically and basally with silver scales; cord with series of irregular longitudinal lines and tiny spots of white hairs, anterior of which are series of ringlike and crescent-shaped white scales; three irregular transverse apical wing bands: basal-most band often broken, white anteriorly (absent or indistinct in some individuals, including the holotype), silver posteriorly; middle and apical-most bands mostly silver, but white at very anterior ends, each almost extending across width of wing.

Male genitalia (Fig. 12).-Abdominal segment IX broad laterally; tergum broad, rounded, 

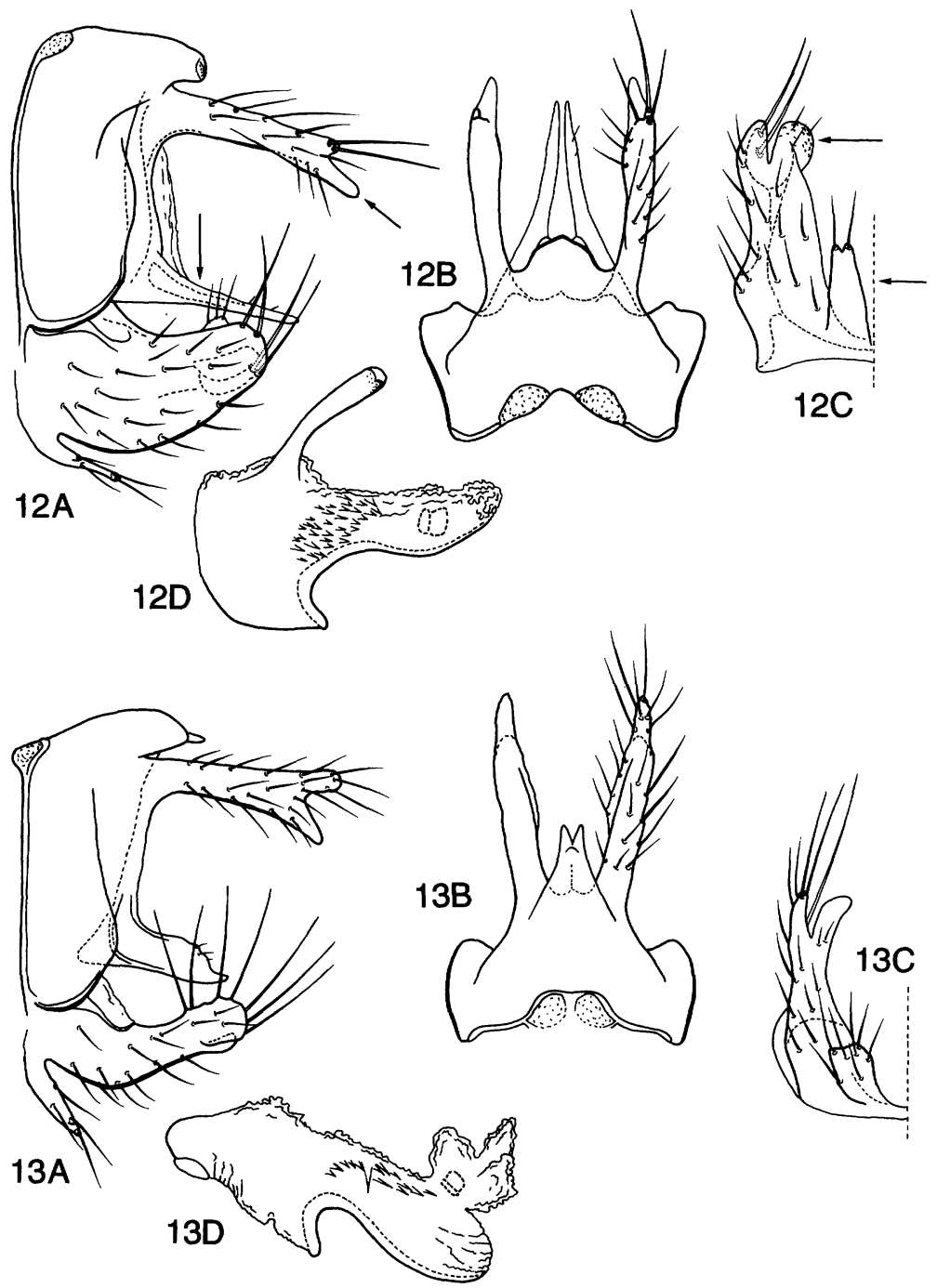

Figs. 12, 13. Nectopsyche spp., male genitalia. 12. - N. tuanis new species. 13.-N. utleyorum new species. Structures and orientations are the same as those in Fig. 1, A-D. Arrows highlight important diagnostic features discussed in the text.

somewhat produced posteriorly. Preanal appendages long, setose, forked apically, each with apicodorsal fork short, setose, apicoventral fork elongate, lacking setae. Segment $\mathrm{X}$ lateral processes thin, very narrow throughout their lengths, bearing small subapical setae. Inferior appendages very broad throughout their lengths, broadly rounded apically, each with small apicodorsal setose lobe; apicomesal lobe broad, rounded, rugose; basoventral process elongate, about twice as long as broad. Phallic apparatus with distinct periphallic processes, each slightly enlarged, pointed, and rugose apically; endothecal membranes highly erectile, bearing about two dozen short spine-like setae; phallotremal sclerite small, U-shaped in dorsal view.

\section{Material examined}

Holotype.-ô: COSTA RICA. Heredia: P. N. Braulio Carrillo, Est. El Ceibo, R. Peje, $10.327^{\circ} \mathrm{N}, 84.078^{\circ} \mathrm{W}$, el. 480 m, 29-31.v.1990, Holzenthal, Blahnik, Muñoz (NMNH). 

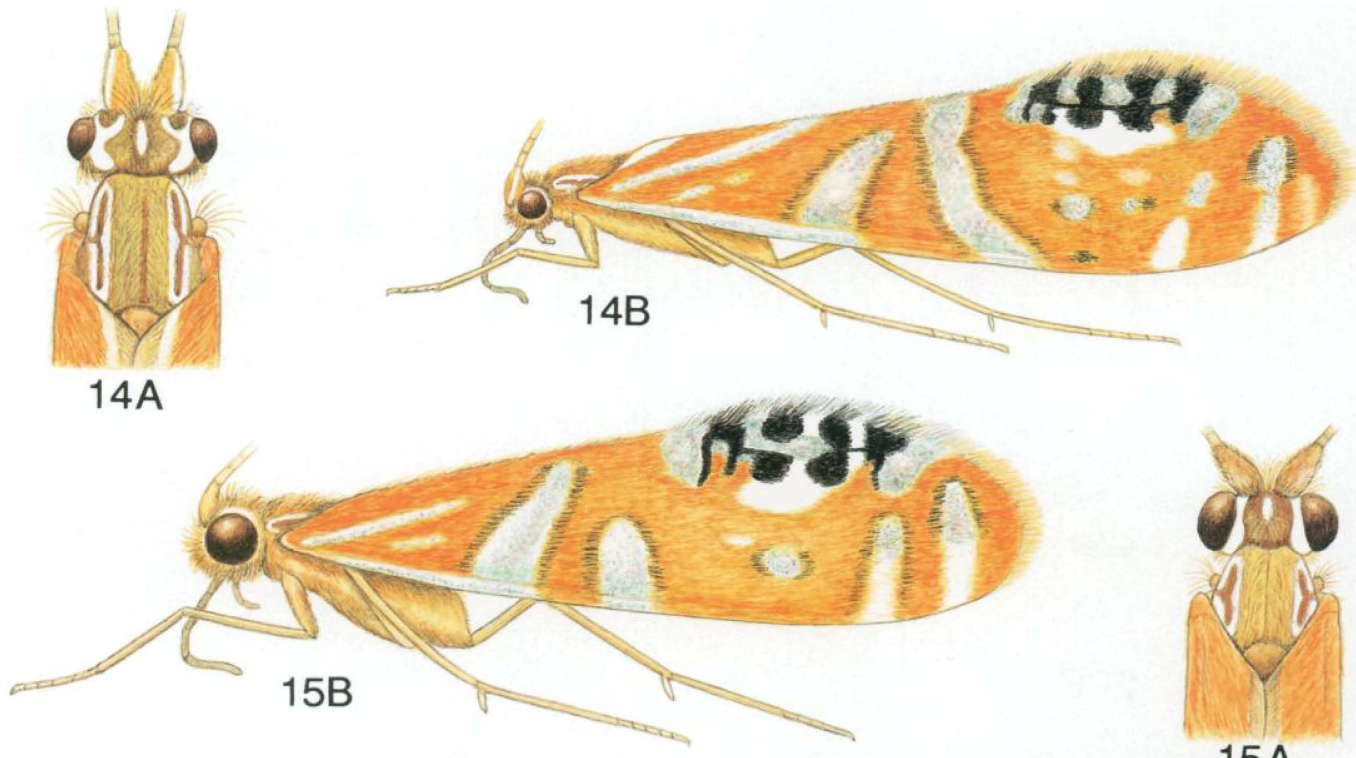

$15 A$
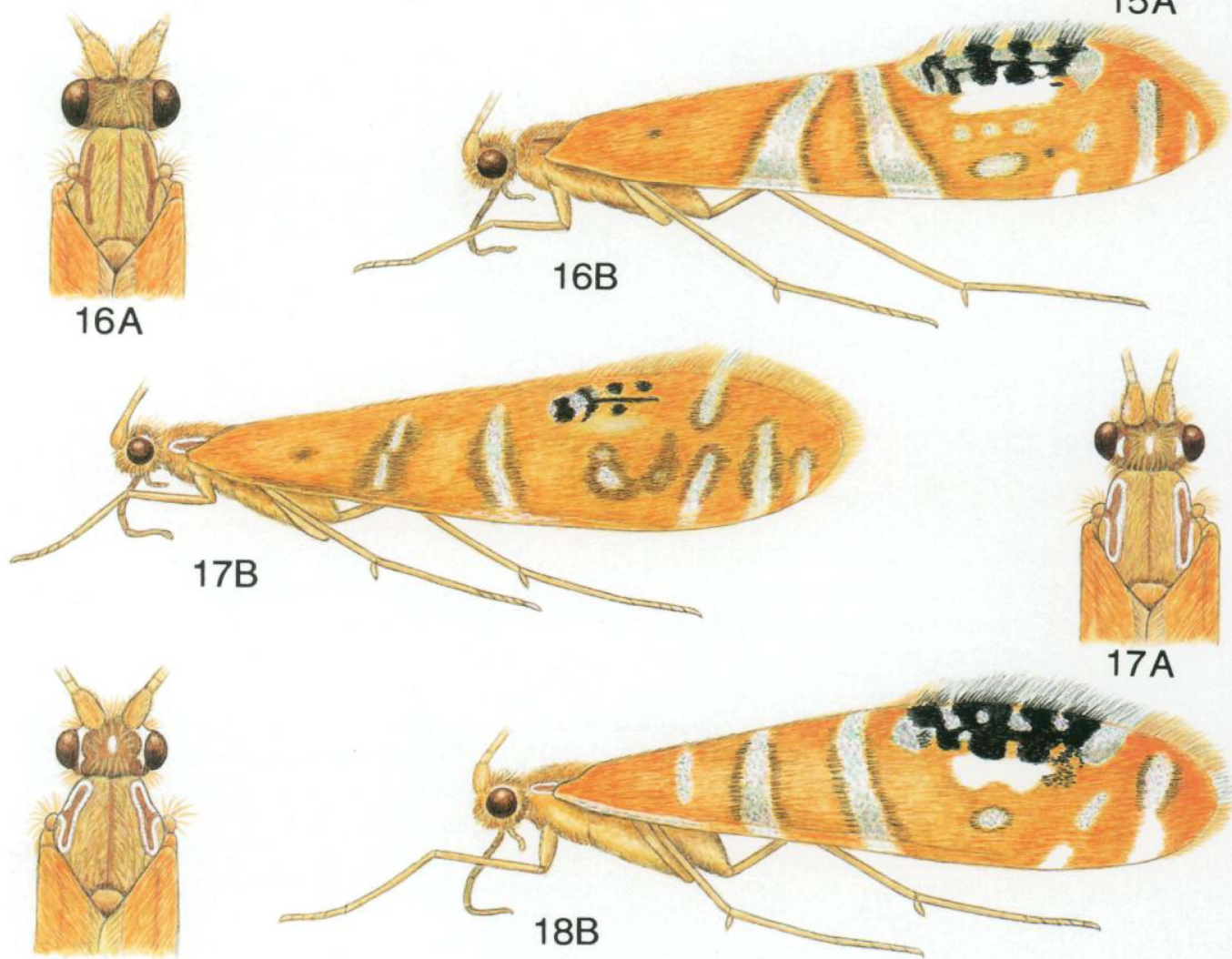

$18 \mathrm{~A}$

Figs. 14-18. Nectopsyche spp. A.-Head and thorax, dorsal. B.-Habitus, lateral. 14. - N. argentata Flint. 15. $-N$. exophthalma new species. 16. $-N$. gemmoides Flint. 17. $-N$. monticola new species. 18. $-N$. onyx new species. 

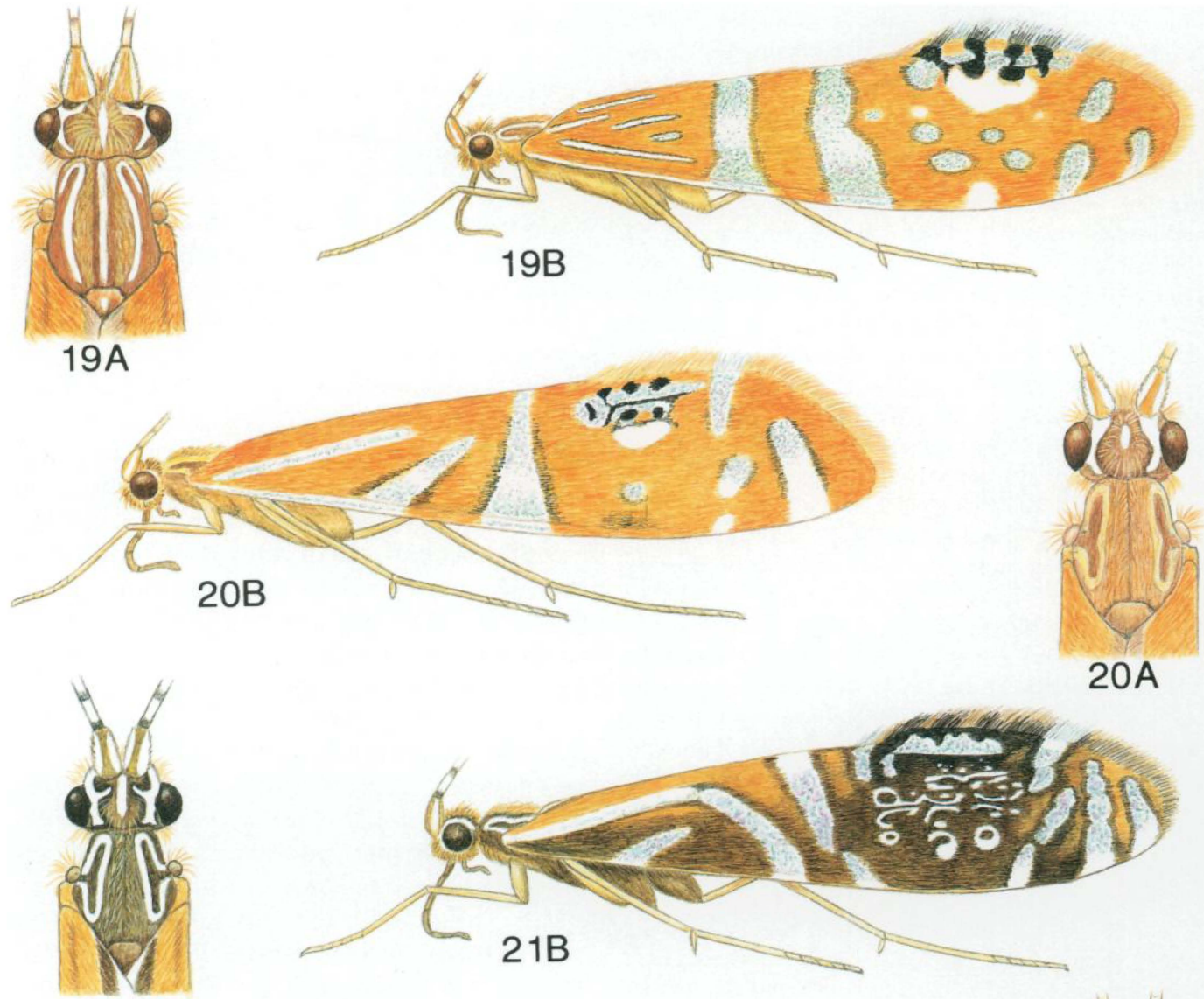

$21 \mathrm{~A}$
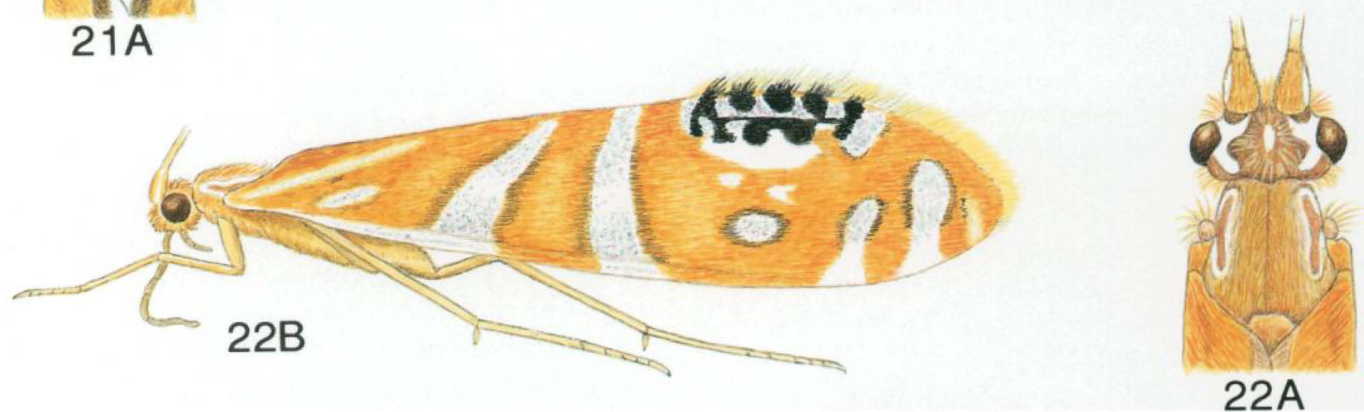

Figs. 19-22. Nectopsyche spp. A.-Head and thorax, dorsal. B. - Habitus, lateral. 19. - N. ortizi new species. 20.-N. tapanti new species. 21. $-N$. tuanis new species. 22. $-N$. utleyorum new species.

Paratypes.-COSTA RICA. Alajuela: Cerro Campana, $\sim 6 \mathrm{~km}$ (air) NW Dos Ríos, $10.9^{\circ} \mathrm{N}, 85.4^{\circ} \mathrm{W}$, el. $640 \mathrm{~m}, 15-16$. iii.1986, Holzenthal, Fasth, 20, 12 \% (UMSP); Cerro Campana, R. Bochinche trib., $6 \mathrm{~km}$ (air) NW Dos Ríos, $10.945^{\circ} \mathrm{N}, 85.413^{\circ} \mathrm{W}$, el. $600 \mathrm{~m}, 22-$ 23.vii.1987, Holzenthal, Morse, Clausen, 5t, 11 의 (UMSP); Reserva Forestal San Ramón, R. San Lorencito and tribs., $10.216^{\circ} \mathrm{N}, 84.607^{\circ} \mathrm{W}$, el. $980 \mathrm{~m}, 1-$ 4.v.1990, Holzenthal, Blahnik, 12 (UMSP); same, except 6-10.iii.1990, Holzenthal, Muñoz, Huisman, 16,
289 (UMSP); same, except 28-30.vii.1990, Holzenthal, Blahnik, Muñoz, 28 (UMSP); same, except 30.iii.1.iv.1987, Holzenthal, Hamilton, Heyn, 16, 14 9 (UMSP); same, except 13-16.vi.1988, C. \& O. Flint, Holzenthal, 19 9 (NMNH); R Sarapiquí, $\sim 2 \mathrm{~km} \mathrm{SE}$ Cariblanco, $10.299^{\circ} \mathrm{N}, 82.172^{\circ} \mathrm{W}$, el. $710 \mathrm{~m}$, 22.vi.1986, Holzenthal, Heyn, Armitage, 19 (UMSP); Cartago: Q. Platanillo, $\sim 5 \mathrm{~km}$ E Moravia de Chirripó, $9.821^{\circ} \mathrm{N}$, $83.407^{\circ} \mathrm{W}$, el. $1130 \mathrm{~m}$, 6.viii.1987, Holzenthal, Morse, Clausen, 19 (UMSP); Reserva Tapantí, Q. Palmitos and 
falls, $9.72^{\circ} \mathrm{N}, 83.78^{\circ} \mathrm{W}$, el. $1400 \mathrm{~m}, 2-3 . v i .1990$, Holzenthal, Blahnik, Muñoz, 5 (UMSP); same, except unnamed tribs., $\sim 9 \mathrm{~km} \mathrm{NW}$ tunnel, $9.72^{\circ} \mathrm{N}, 83.78^{\circ} \mathrm{W}$, el. 1400 m, 8-9.vi.1988, C. \& O. Flint, Holzenthal, 1 우 $(\mathrm{NMNH}) ; \mathrm{R}$. Chitaria, route $10,10 \mathrm{~km} \mathrm{NE}$ R. Reventazón, $9.920^{\circ} \mathrm{N}, 83.604^{\circ} \mathrm{W}$, el. $740 \mathrm{~m}, 21$. iii.1991, Holzenthal, Muñoz, Huisman, 8 ㅇ (UMSP); km 10, Tur-

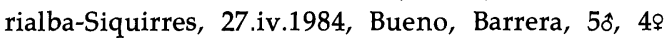
(IBUNAM); Guanacaste: Parque Nacional Guanacaste, $\sim 0.7 \mathrm{~km} \mathrm{~N}$ Est. Maritza, $10.96^{\circ} \mathrm{N}, 85.50^{\circ} \mathrm{W}$, el. 550 m, 31.viii.1990, Huisman, Quesada, 19 (UMSP); Parque Nacional Guanacaste, Estación Pitilla, R. Orosí, $10.991^{\circ} \mathrm{N}, 85.428^{\circ} \mathrm{W}, 22-25 . v .1990$, el. $700 \mathrm{~m}$, Holzenthal, Blahnik, 3ô, 3ㅇ (INBIO); same, except 1920.vi.1988, C. \& O. Flint, Holzenthal, 1o, 9 ㅇ (NMNH); Parque Nacional Guanacaste, Maritza, R. Tempisquito, $10.958^{\circ} \mathrm{N}, 85.497^{\circ} \mathrm{W}$, el. $550 \mathrm{~m}, 19-20$.vii.1987, Holzenthal, Morse, Clausen, 5 (UMSP); same, except 3031.viii.1990, Huisman, Blahnik, Quesada, 39 (UMSP); same, except 17-18.vi.1988, C. \& O. Flint, Holzenthal, 14ô, 11 (NMNH); Heredia: P. N. Braulio Carrillo, Est. Magsasay, R. Peje, $10.402^{\circ} \mathrm{N}, 84.050^{\circ} \mathrm{W}$, el. $130 \mathrm{~m}$, Holzenthal, Blahnik, Huisman, 20, 1 우 (INBIO); same data as holotype, 20太, 19 ㅇ (UMSP); R. Bijagual on road to Magsasay, $10.408^{\circ} \mathrm{N}, 84.076^{\circ} \mathrm{W}$, el. $140,12.1 i .1986$, Holzenthal, Morse, Fasth, 19 (UMSP); Limón: Parque Nacional Braulio Carrillo, Q. González, $10.160^{\circ} \mathrm{N}$, $83.939^{\circ} \mathrm{W}$, el. $480 \mathrm{~m}, 12-14 . v .1990$, Holzenthal, Blahnik, 3ô, 3 ㅇ (UMSP); Puntarenas: R. Bellavista, $\sim 1.5$ $\mathrm{km} \mathrm{NW}$ Las Alturas, $8.951^{\circ} \mathrm{N}, 82.846^{\circ} \mathrm{W}$, el. $1400,15-$ 17.vi.1986, Holzenthal, Heyn, Armitage, 3\% (UMSP); same, except 16-17.vi.1991, Holzenthal, Muñoz, Huisman, 1 ( (UMSP); R. Guineal, $\sim 1 \mathrm{~km}$ (air) E Finca Helechales, $9.076^{\circ} \mathrm{N}, 83.092^{\circ} \mathrm{W}$, el. 840 , 4.viii.1987, Holzenthal, Morse, Clausen, $1 \delta^{\hat{\alpha}}, 2 \circ$ (UMSP); same, except 22.ii.1986, Holzenthal, Morse, Fasth, $3 \hat{\delta}, 3 \uparrow$ (INBIO); R. Singrí, $2 \mathrm{~km}$ (air) S Finca Helechales, $9.057^{\circ} \mathrm{N}$, $83.082^{\circ} \mathrm{W}$, el. $720 \mathrm{~m}, 21 . i 1.1986$, Holzenthal, Morse, Fasth, 10, 2 (UMSP); San Jóse: P. N. Braulio Carrillo, Est. Carrillo, Q. Sanguijuela, $10.160^{\circ} \mathrm{N}, 83.963^{\circ} \mathrm{W}$, el. 800 m, 27.iii.1987, Holzenthal, Hamilton, Heyn, 2ô, 38 (UMSP); same, except 11-12.vi.1988, C. \& O. Flint, Holzenthal, 35 \% (NMNH).

\section{Etymology}

Tuanis is a Costa Rican colloquialism, mainly used among boys and young men in San José, that roughly translates in North American English slang to "neat", "cool", or "very nice".

\section{Nectopsyche utleyorum new species} Figs. 13, 22

Nectopsyche argentata Flint 1991:94 [in part, all paratypes listed by Flint 1991:94-95 from
Costa Rica, except 11ð from Parque Nacional Guanacaste, Maritza, 17-18.vii.1988, are here referred to $N$. utleyorum].

\section{Diagnosis}

This species is very similar to several of those described above, especially N. argentata, N. gemmoides, and $N$. onyx. It is not $N$. argentata, where the form was originally placed, but a different species. The most distinctive differences between the two are the lack of the patch of white hairs at the jugum in N. utleyorum, the punctation around the cord, and differences in the male genitalia (see diagnosis of $N$. argentata above). Nectopsyche utleyorum and $N$. onyx also have similar patterns of color on the apical half of the forewing, a character they share with $N$. gemmoides, especially the dominant oval silver spot on the cord present in all three. Furthermore, in some, although very few, individuals of N. utleyorum, I have seen the characteristic $N$.gemmoides dash of black scales anterior to the apical-most spot along Cu1b. Also, I have seen some individuals of $N$. utleyorum with less distinct silver stripes basally on the wing, approaching the unstriped condition of $N$. gemmoides. The genitalia of $N$. utleyorum and N. ony $x$ are essentially indistinguishable, but the latter species is distinctly smaller than the former, and while both $N$. utleyorum and many $N$. ony $x$ lack periphallic processes, these are definitely present in $N$. gemmoides. A combination of characters must therefore be used to separate the three species: $N$. gemmoides has distinct periphallic processes whereas $N$. ony $x$ and $N$. utleyorum lack these processes or they are vestigial; $N$. ony $x$ has a third, transverse basal wing band and no longitudinal stripes, whereas $N$. utleyorum has longitudinal stripes in this area and is much larger in overall size than $N$. onyx.

\section{Description}

Adult (Fig. 22).-Forewing length $9.5 \mathrm{~mm}\left({ }^{\circ}\right)$, $6.5 \mathrm{~mm}$ (). Head straw colored, covered with yellow hairs, dorsally with white scales and hairs bordering eyes and with white patch on vertex; antennal scapes yellow with narrow lateral and mesal stripes of white scales; antennal flagellomeres yellowish white. Eyes small. Thorax straw colored, covered with yellow and golden hairs; mesoscutum with elongate patch of white 
scales laterally; legs straw colored. Forewings covered with golden-yellow hairs. Base of each forewing with long stripe of silver scales along base of $\mathrm{A} 1+\mathrm{A} 2$, shorter stripe of silver scales along base of $M$, and silver scales between $C$ and Sc extending to basal transverse band. Middle of forewing with two broad transverse bands of silver scales bordered by fuscous hairs: basalmost band extending from $\mathrm{C}$ almost to anal margin, narrowing along its length and tilted apicad; apical-most band extending across width of wing, slightly curved, and narrowing slightly throughout its length. Large spots of black scales along $\mathrm{Cu} 1 \mathrm{~b}$, these set in silver scales posteriorly and laterally and with oval patch of white scales anteriorly, basal-most black spot roughly U-shaped, remaining spots roughly figure- 8 shaped connected to each other by narrow longitudinal stripe of black scales, in very few specimens there is small dash of black scales anterior of apical spot (as in N. gemmoides); cord with single oval spot of silver scales bordered by fuscous hairs, posterior of which may be small silver spot and one or two very small white spots; three transverse apical wing bands: basal and middle bands constricted mesally, white anteriorly, silver posteriorly, the silver bordered by fuscous hairs; apical band white, narrow, faint, often absent.

Male genitalia (Fig. 13).-Abdominal segment IX broad laterally; tergum broad, rounded, somewhat produced posteriorly. Preanal appendages long, setose, forked apically, each with apicoventral fork long, thin, setose basally. Segment $X$ lateral processes thin, broad mesally, abruptly narrowed and pointed apically, bearing small subapical setae. Inferior appendages relatively narrow throughout length, rounded apically, with numerous long setae; each with apicomesal lobe narrowly rounded apically, slightly turned mesally, with long seta near gap where apicomesal lobe originates from body of inferior appendage; basoventral process broad, about as long as wide. Phallic apparatus without periphallic processes; endothecal membranes highly erectile, bearing about 10-15 short spinelike setae; phallotremal sclerite small, U-shaped in dorsal view.

\section{Material examined}

Holotype. -ô: COSTA RICA. Puntarenas: Reserva Bosque Nubosa Monteverde, Q. Cuecha, $10.31^{\circ} \mathrm{N}$,
84.79 W, el. $1550 \mathrm{~m}, 28.1 i .1986$, Holzenthal, Fasth (NMNH).

Paratypes.-COSTA RICA. Alajuela: Cerro Campana, R. Bochinche trib., $6 \mathrm{~km}$ (air) NW Dos Ríos, $10.645^{\circ} \mathrm{N}, 85.413^{\circ} \mathrm{W}$, el. $600 \mathrm{~m}, 15-16.1 i i .1986$, Holzenthal, Fasth, 1ô (UMSP); same, except 22-23.vii.1987,

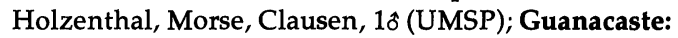
Parque Nacional Guanacaste, Est. Mengo, R. San Josecito, $10.922^{\circ} \mathrm{N}, 85.470^{\circ} \mathrm{W}$, el. $960 \mathrm{~m}, 28-29 . v i i .1987$, Holzenthal, Morse, Clausen, 69 (UMSP); Parque Nacional Rincón de la Vieja, R. Negro, $10.765^{\circ} \mathrm{N}, 85.313^{\circ} \mathrm{W}$, el. 810 m, 3.iii.1986, Holzenthal, Fasth, 20, 19 (UMSP); Parque Nacional Guanacaste, Maritza, R. Tempisquito, $10.958^{\circ} \mathrm{N}, 85.497^{\circ} \mathrm{W}$, el. $550 \mathrm{~m}$, Holzenthal, Morse, Clausen, 1ô (NMNH); Puntarenas: same data as holotype, 5 ㅇ (UMSP); R. Bellavista, $\sim 1.5 \mathrm{~km} \mathrm{NW} \mathrm{Las}$ Alturas, $8.951^{\circ} \mathrm{N}, 82.846^{\circ} \mathrm{W}$, el. $1400 \mathrm{~m}, 8-9 . i v .1987$, Holzenthal, Hamilton, Heyn, 7^ (UMSP); same, except 2-3.viii.1987, Holzenthal, Morse, Clausen, 29 (UMSP); same, except 18.ii.1986, Holzenthal, Morse, Fasth, 5ô (UMSP); same, except 16-17.iii.1991, Holzenthal, Muñoz, Huisman, 30े, 2 (UMSP); same, except 10-11.viii.1990, Holzenthal, Blahnik, Muñoz, 2ô (INBIO); R. Cotón in Las Alturas, $8.938^{\circ} \mathrm{N}, 82.826^{\circ} \mathrm{W}$, el. $1360 \mathrm{~m}$, 16.ii.1986, Holzenthal, Morse, Fasth, 20ิ (UMSP); trib. to R. Bellavista in Las Alturas (road to quarry), $8.952^{\circ} \mathrm{N}, 82.848^{\circ} \mathrm{W}$, el. $1480 \mathrm{~m}, 13-14 . v i i i .1990$, Holzenthal, Blahnik, Muñoz, 1ô, 19 (INBIO); same, except 19.iii.1991, Holzenthal, Muñoz, Huisman, 3ô (UMSP).

\section{Etymology}

Named in honor of Dr. John F. Utley and Dr. Kathy Burt-Utley, tropical plant systematists at the University of New Orleans, who first introduced me to the tropics, thus initiating my interest in the rich diversity of the tropical world.

\section{Acknowledgements}

This research is largely based on support from the National Science Foundation grants BSR8512368 and BSR-8917684. This support is gratefully acknowledged. Part of this work, mainly the generic diagnosis and larval illustrations, was completed at Clemson University. The support of that institution, and especially Dr. John C. Morse, is gratefully acknowledged. Additional support has been received from a Grantin-Aid for Research (000-0959-2217-04) from the Graduate School, University of Minnesota. Support for field work in Costa Rica in 1988 and 1989 was received from the Nature Conservancy, Minnesota Chapter, and the Office of Inter- 
national Education, University of Minnesota, respectively.

I am especially thankful to Julie Janke, Afton, Minnesota, for the exquisite color illustrations of the adults. Sincere appreciation is extended to Jolanda Huisman for her thorough review of the manuscript. Dr. Joaquín Bueno-Soria and Dr. Silvia Santiago Fragoso, Instituto de Biología, Universidad Nacional Autónoma de México, graciously assisted in the loan of specimens from their institution. Dr. Oliver S. Flint, Jr., National Museum of Natural History, has been an invaluable source of support in acquiring literature and loaning specimens. $\mathrm{He}$ and his wife, Carol Flint, provided pleasant companionship during our 1988 trip to Costa Rica. I thank all those who have assisted me in the field in Costa Rica, but especially Jolanda Huisman, Fernando Muñoz, and Roger Blahnik. The assistance of the Servicio de Parques Nacionales and the Instituto Nacional de Biodiversidad, Costa Rica, is gratefully acknowledged. Finally, I am grateful to Dr. John K. Jackson, Stroud Water Research Center, for inviting me to contribute this paper to J-NABS. Paper No. 20,967, Scientific Journal Series, Minnesota Agricultural Experiment Station, St. Paul, Minnesota.

\section{Literature Cited}

BANKs. N. 1899. Descriptions of new North American neuropteroid insects. Transactions of the American Entomological Society 25:199-218.

BETTEN, C. 1934. The caddis flies or Trichoptera of New York State. Bulletin of the New York State Museum 292:1-576, plates 1-67.

BotosaneANU, L., AND O. S. Flint. 1982. On some Trichoptera from northern Venezuela and Ecuador (Insecta). Beaufortia 32:13-26.

DAIGLE, J. J., AND J. D. HADDOCK. 1981. The larval description and ecological notes of a caddisfly, Nectopsyche tavara (Ross), from the central Florida refugium. Pan-Pacific Entomologist 57:327-331.

ELKINS, W. A. 1936. The immature stages of some Minnesota Trichoptera. Annals of the Entomological Society of America 29:656-682.

FISCHER, F. C. J. 1966. Leptoceridae, pars 2. Trichopterorum Catalogus, Vol. VII. Nederlandse Entomologische Vereniging, Amsterdam.

FIsCHER, F. C. J. 1972. Supplement to Vol. V, VI, and VII. Trichopterorum Catalogus, Vol. XIV. Nederlandse Entomologische Vereniging, Amsterdam.

FLINT, O. S. 1968. The caddisflies of Jamaica (Tri- choptera). Bulletin of the Institute of Jamaica, Science Series 19:1-68.

Flint, O.S. 1972. Studies of Neotropical caddisflies, XIV: on a collection from northern Argentina. Proceedings of the Biological Society of Washington 85:223-248.

FLINT, O.S. 1974a. Studies of Neotropical caddisflies, XV: the Trichoptera of Surinam. Studies on the fauna of Suriname and other Guyanas 14(55):1151, plates 1-4.

FLINT, O.S. 1974b. Checklist of the Trichoptera, or caddisflies, of Chile. Revista Chilena de Entomología 8:83-93.

FLINT, O. S. 1981. Studies of Neotropical caddisflies, XXVIII: the Trichoptera of the Río Limón Basin, Venezuela. Smithsonian Contributions to Zoology 330:1-61.

Flint, O. S. 1982. Trichoptera of the Area Platense. Biología Acuatica 2:1-70.

FLINT, O. S. 1983. Studies of Neotropical caddisflies, XXXIII: new species from austral South America (Trichoptera). Smithsonian Contributions to Zoology 377:1-100.

FLINT, O.S. 1991. Studies of Neotropical caddisflies, XLV: the taxonomy, phenology, and faunistics of the Trichoptera of Antioquia, Colombia. Smithsonian Contributions to Zoology 520:1-113.

HADDOCK, J. D. 1977. The biosystematics of the caddis fly genus Nectopsyche in North America with emphasis on the aquatic stages. American Midland Naturalist 98:382-421.

HolzentHAL, R. W. 1985. Studies of Neotropical Leptoceridae (Trichoptera): their diversity, evolution, and biogeography, with revisions of selected genera. Ph.D. Dissertation, Clemson University, Clemson, South Carolina.

Kolenati, F. A. 1859. Genera et species Trichopterorum, pars altera. Nouveaux Mémoires de la Société Impériale des Naturalistes de Moscou 11: 141-296, plates 1-5.

MARLIER, G. 1964. Trichoptères de l'Amazonie recueillis par le Professeur H. Sioli. Memoires Institut Royal des Sciences Naturelles de Belgique, series 2, fasc. 76:1-167.

MerritT, R. W., AND K. W. Cummins (editors). 1984. An indroduction to the aquatic insects of North America. 2nd edition. Kendall/Hunt, Dubuque, Iowa.

MILNE, L. J. 1934. Studies in North American Trichoptera, Part 1, pages 1-19. Privately published. Cambridge, Massachusetts.

MORSE, J. C. 1975. A phylogeny and revision of the caddisfly genus Ceraclea (Trichoptera, Leptoceridae). Contributions of the American Entomological Institute 11:1-97.

MORSE, J. C. 1981. A phylogeny and classification of family-group taxa of Leptoceridae (Trichoptera). Pages 257-263 in G. P. Moretti (editor). Proceed- 
ings of the Third International Symposium on Trichoptera. Dr. W. Junk Publishers, The Hague.

MülLER, F. 1879. Über Phryganiden (letters to his brother). Zoologischer Anzeiger 2:38-40, 180-182, 283-284, 405-407.

MÜLLER, F. 1880. Sobre as casa contruida pelas larvas de insecto Trichopteros da Provincia de Santa Catharina. Archivos do Museu Nacional, Rio de Janeiro 3:99-134, 210-214, plates 8-11.

MÜLLER, F. 1921. Briefe und noch nicht veröffentliche Abhandlunger aus dem Nachlass 18541897. In A. Möller (editor). Fritz Müller: Werke, Briefe und Leben, 2:xvii + 667. Gustav Fischer, Jena.

NAVÁs, L. 1920. Insectos Sudamericanos (1a, 2a y 3a serie). Anales de la Sociedad Cientifica Argentina 90:33-72.

RoBACK, S. S. 1966. The Trichoptera larvae and pupae, Chapter XI. Pages 235-303 in R. Patrick (editor). The Catherwood Foundation Peruvian Amazon Expedition: limnological and systematic studies. Monographs of the Academy of Natural Sciences of Philadelphia 14:1-495.

RoldÁN PÉrez, G. 1988. Guía para el Estudio de los Macroinvertebrados Acuáticos del Departamento de Antioquia. Universidad de Antioquia, Antioquia.
Ross, H. H. 1944. The caddis flies, or Trichoptera, of Illinois. Bulletin of the Illinois Natural History Survey 23:1-326.

SCHMID, F. 1949. Les Trichoptères de la collection Navás. Eos 25:305-426.

SCHMID, F. 1980. Les insects et arachnides du Canada, Partie 7: genera des Trichoptères du Canada et des États adjacents. Agriculture Canada, Ottawa.

ULMER, G. 1907. Trichopteren. In P. Wytsman (editor). Genera Instectorum, part 60. Brussels.

ULMER, G. 1951. Köcherfliegen (Trichopteren) von den Sunda-Inseln (Teil I). Archiv für Hydrobiologie, Supplement 19:1-528, plates 1-28.

UlmeR, G. 1955. Köcherfliegen (Trichopteren) von den Sunda-Inseln, Teil II. Archiv für Hydrobiologie, Supplement 21:408-608, plates 10-17.

VorhIEs, C. T. 1909. Studies on the Trichoptera of Wisconsin. Transactions of the Wisconsin Academy of Science 16:647-738, plates 52-61.

Wiggins, G. B. 1977. Larvae of the North American caddisfly genera (Trichoptera). University of Toronto Press, Toronto.

Received: 17 January 1994 Accepted: 24 October 1994 